\title{
Effect of different levels of synthetic astaxanthin on growth, skin color and lipid metabolism of commercial sized red porgy (Pagrus pagrus)
}

\author{
Natacha Nogueira ${ }^{\text {a,b,c, } * \text {, Paula Canada }}{ }^{\text {b,c }}$, José Caboz ${ }^{\mathrm{d}}$, Carlos Andrade ${ }^{\mathrm{a}, \mathrm{b}, \mathrm{c}}$, \\ Nereida Cordeiro ${ }^{c, d}, * *$ \\ ${ }^{a}$ Mariculture Center of Calheta, Regional Directorate for the Sea, 9370-155, Calheta, Portugal \\ ${ }^{\mathrm{b}}$ Oceanic Observatory of Madeira, ARDITI, Madeira Tecnopolo, 9020-105, Funchal, Portugal \\ ${ }^{\mathrm{c}}$ CIIMAR - Interdisciplinary Center of Marine and Environmental Research, University of Porto, 4450-208, Matosinhos, Portugal \\ ${ }^{\mathrm{d}}$ LB3, Faculty of Science and Engineering, University of Madeira, 9020-105, Funchal, Portugal
}

\section{A R T I C L E I N F O}

\section{Keywords:}

Pagrus pagrus

Carophyll ${ }^{\circledR}$ pink

Color

Astaxanthin

Lipids

\begin{abstract}
A B S T R A C T
A study was undertaken to evaluate the effects of supplementing commercial feeds with Carophyll ${ }$ Pink, a gelatin-encapsuled astaxanthin, on growth parameters, lipid composition, pigment concentration and skin color of commercial size red porgy. Three isonitrogenous diets were formulated containing different levels of astaxantin: Ctrl diet (no pigment added), $\mathrm{A}_{50}$ diet (with $50 \mathrm{mg} / \mathrm{kg}$ of astaxanthin) and $\mathrm{A}_{80}$ diet (with $80 \mathrm{mg} / \mathrm{kg}$ of astaxanthin). Four groups of fish ( $386.29 \pm 29.50 \mathrm{~g}$ initial weight) were grown in triplicate tanks (10 fish per tank). Ctrl, $\mathrm{A}_{50}$ and $\mathrm{A}_{80}$ groups were fed the respective diets to apparent satiation for 180 days, while a fourth group was fed $A_{50}$ diet for 90 days followed by $A_{80}$ diet for another 90 days $\left(A_{50} A_{80}\right)$. At the end of trial muscle samples were collected for composition analysis, liver and mesenteric fat for lipid composition determination and skin samples for carotenoids quantification. Dietary astaxanthin supplementation had no effect on growth performance and hepatosomatic index. However, $\mathrm{A}_{50} \mathrm{~A}_{80}$ group displayed a lower muscle protein content and higher fat content when compared to the other groups. There was no clear effect of dietary astaxanthin supplementation on the liver's and mesenteric fatty acid profile. Although there was no significant effect on skin total carotenoids, the astaxanthin content tended to increase in fish fed astaxanthin supplemented diets, which was reflected on redness values. Accordingly, dietary astaxanthin supplementation (at 50 or $80 \mathrm{mg} / \mathrm{kg}$ for 6 months or at $50 \mathrm{mg} / \mathrm{kg}$ for 3 months followed by $80 \mathrm{mg} / \mathrm{kg}$ for 3 months) influenced positively skin hue and chroma of red porgy on both pectoral and caudal areas, improving the skin color in commercial sized red porgy and achieving hue and chroma values close to those previously reported for wild individuals. The results reported here provide evidence
\end{abstract}

Abbreviations: Ctrl, diet not supplemented with astaxanthin; $\mathrm{A}_{50}$, diet supplemented with $50 \mathrm{mg} / \mathrm{kg}$ of astaxanthin; $\mathrm{A}_{80}$, diet supplemented with $80 \mathrm{mg} / \mathrm{kg}$ of astaxanthin; $\mathrm{A}_{50} \mathrm{~A}_{80}$, diet supplemented with $50 \mathrm{mg} / \mathrm{kg}$ of astaxanthin for three months followed with $80 \mathrm{mg} / \mathrm{kg}$ of astaxanthin for the three next months; IBW, initial body weight; FBW, final body weight; SGR, specific growth rate; DGI, daily growth index; FCR, feeding conversion ratio; PER, protein efficiency ratio; HIS, hepatosomatic index; L*, lightness; $a^{*}$, redness/greenness chromaticity; $b^{*}$, yellowness/bluish chromaticity; TL, total lipids; MUFA, monounsaturated fatty acids; PUFA, polyunsaturated fatty acids; SFA, saturated fatty acids; DHA, docosahexaenoic acid

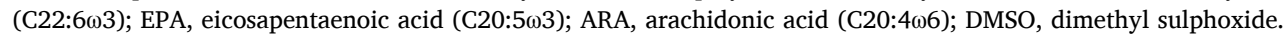

* Corresponding author at: Mariculture Center of Calheta, Vila da Calheta, 9370-155, Calheta, Portugal.

** Corresponding author at: Faculty of Science and Engineering, University of Madeira, 9020-105, Funchal, Portugal.

E-mail addresses: natacha.nogueira@madeira.gov.pt, natachacnogueira@gmail.com (N. Nogueira), ncordeiro@staff.uma.pt (N. Cordeiro). 
of the applicability of Carophyll ${ }^{\circledR}$ Pink to improve skin color of large size commercial red porgy, but further studies are needed to optimize this carotenoid supplementation in production farming.

\section{Introduction}

There is a great challenge of supplying fish to an increasing and demanding market of animal proteins for human consumption. The undertaking of diversification processes within aquaculture industry is essential to maintain high production growth rates. The red porgy (Pagrus pagrus) is a protogynous hermaphrodite sparid fish widely distributed in the temperate zone of both sides of the Atlantic Ocean and Mediterranean Sea (Manooch, 1975). In the past, several studies showed that this high price species presented a good adaptability and a high growth rate in captivity (Pavlidis and Mylonas, 2011). Hatchery techniques for this species evolved from other sparids culture and are well established (Aristzabal et al., 2009; Morris et al., 2008; Andrade et al., 2011, 2012, 2013). However, under culture conditions, the natural red-silver color of red porgy body changes into an overall dark grey, most prominently in the tail and fins, differentiating from wild counterparts (Stephanou et al., 1995; Cejas et al., 2003; Almansa et al., 2001; Pavlidis et al., 2008; Kalinowski et al., 2015) and hence remaining as the bottleneck for the commercialization of the species.

Fish flesh and skin color is due to the presence of oxygenated carotenoids or xanthophylls (da Costa and Miranda-Filho, 2020), an important class of pigments in animals, synthesized by all photosynthetic organisms (Carvalho and Caramujo, 2017). Nevertheless, teleost fish do not possess the ability to synthesize carotenoids endogenously (Goodwin, 1984), but they can modify dietary carotenoids and store them in the integument and other tissues. In the wild, fish obtain carotenoids from prey, but in intensive fish cultures, the carotenoids requirements should be met through dietary additives (Noori and Razi, 2017). Still, carotenoids deposition and pigmentation efficiency are source-dependent and species-specific (Ha et al., 1993), as not all fish species possess the same pathways for metabolizing carotenoids.

The carotenoid compounds have also been associated with other biological functions such as the synthesis of vitamin A (White et al., 2003), immune functions (Amar et al., 2012) and high antioxidant activity (Wang et al., 2006), preventing the harmful effects of lipid peroxidation (Liebler, 1993). Together with lipid protection, carotenoids may as well exert influence on lipogenesis and lipid composition (Mary et al., 2003; Trattner et al., 2007; Woo et al., 2010; Hu et al., 2012). Marine fish lipids, namely the docosahexaenoic

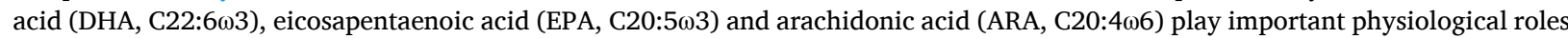
in fish as components of membranes phospholipids and as precursors of active eicosanoids (Bell and Sargent, 2003). As in other marine fish, red porgy tissues are naturally enriched with these fatty acids (Rueda et al., 1997; Cejas et al., 2003). Dietary supplementation with carotenoids has been shown to decrease total lipids in the whole fish and liver, as well as palmitic acid (C16:0) (Kalinowski et al., 2011), and to increase liver EPA and DHA content (Kalinowski et al., 2011). Conversely, there is a controversy regarding the effect of carotenoids on growth (Chatzifotis et al., 2005; Kalinowski et al., 2015). Although some studies reported growth enhancement with carotenoid supplementation (Torrissen et al., 1995; Christiansen and Torrissen, 1996; Amar et al., 2001), others have found no effect at all (Nakano et al., 1995; Nickell and Bromage, 1998; Rahman et al., 2016).

The keto-carotenoid astaxanthin (3,3'-dihydroxy- $\beta, \beta$-carotene-4,4'-dione) is the main carotenoid responsible for the reddish or pinkish color of most wild fish (Dhankhar et al., 2012; Carvalho and Caramujo, 2017). Therefore, many studies used it, from natural or synthetic sources, to induce pink or red skin coloration (Tejera et al., 2007; Chatzifotis et al., 2011; Kalinowski et al., 2011, 2015). The continued growth of the aquaculture industry has led to a massive demand for astaxanthin (Lim et al., 2018). Nowadays, the commercialization of the synthetic products is widespread not only because it lowers the pigments production costs (Lim et al., 2018), but because these are standardized products, chemically stable with high carotenoid concentration (Teimouri and Amirkolaie, 2015). Still, carotenoid supplementation in aquaculture feeds, further increases the already high management costs (Lim et al., 2018), decreasing profits in aquaculture operation (Pham et al., 2014). For that reason, the research on supplementation protocols to optimize the inclusion of these pigments in commercial sized fish is key to assure profitability. To our knowledge previous studies on red porgy tegument coloration dealt with alevins and juveniles up to $220 \mathrm{~g}$ at the beginning of the experiments. Surprisingly, larger sized fish (600 g) have received little attention though it is more valued and with a higher potential for product diversification in several Mediterranean countries (e.g. filleting) (Basurco et al., 2011). Therefore, the purpose of the current study was to investigate the effects of supplementing commercial feeds with Carophyll® Pink, a gelatin-encapsuled astaxanthin, on large commercial sized red porgy growth parameters and lipid composition. Red porgy juveniles were fed two astaxanthin supplementation levels and a third group was sought to ascertain whether an increase in astaxanthin concentration would lead to a change in retention efficiency, ultimately affecting feed production costs. To accomplish the objective of this study, the following parameters were evaluated: growth performance, skin pigmentation, tissues proximate composition (dry matter, ash, crude protein and total lipid), lipid classes and fatty acid composition of the liver and mesenteric fat.

\section{Material and methods}

\subsection{Experimental diets and dietary treatments}

A diet formulated to meet the nutritional requirements of Sparidae (Guillaume and Choubert, 2001; Koshio, 2002; Schuchardt et al., 2007; Kalinowski et al., 2011) was used as a control diet (Ctrl), not being supplemented with astaxanthin. Two other diets were 
supplemented with $50 \mathrm{mg} / \mathrm{kg}$ (diet $\mathrm{A}_{50}$ ) and $80 \mathrm{mg} / \mathrm{kg}$ (diet $\mathrm{A}_{80}$ ) of synthetic astaxanthin $\left(3,3^{\prime}\right.$-dihydroxy- $\beta, \beta$-carotene-4, $4^{\prime}$-dione) (Carophyll ${ }^{\circledR}$ Pink $10 \%$ CWS, DSM Nutritional Products Ltd). Astaxanthin was prediluted with a mineral carrier and added to the mixer prior to extrusion, to ensure homogeneous mixing occurred. The formulation included antioxidants to minimize losses of the pigment due to oxidative stress. All feeds were formulated and manufactured by Aquasoja (Soja de Portugal, Portugal). Ingredients, diet composition and the carotenoid content of the diets are presented in Table 1.

Four groups were assigned different dietary treatments. The Ctrl, $A_{50}$ and $A_{80}$ groups were fed the Ctrl, $A_{50}$ and $A_{80}$ diets, respectively, for six months. A fourth group $\left(A_{50} A_{80}\right)$ was fed upon the $A_{50}$ diet for three months followed by the $A_{80}$ diet for the next three months.

\subsection{Husbandry and experimental set-up}

One hundred and twenty red porgy (Pagrus pagrus) juveniles hatched and reared at Mariculture Center of Calheta (CMC) facilities, with an average initial weight of $386.29 \pm 29.50 \mathrm{~g}$, were distributed by twelve white circular fiberglass $500 \mathrm{~L}$ white tanks in a flowthrough system, at an initial density of $7.5 \mathrm{~kg} / \mathrm{m}^{3}$. Prior to the beginning of the trial, fish underwent a 2-weeks acclimation period and were fed the Ctrl non-carotenoid supplemented diet. Then, the dietary treatments ( $\mathrm{Ctrl}, \mathrm{A}_{50}, \mathrm{~A}_{80}, \mathrm{~A}_{50} \mathrm{~A}_{80}$ ) were randomly assigned to the twelve tanks (three tanks per treatment). Throughout the trial, fish were exposed to natural photoperiod (10 h light/14 h dark), dissolved oxygen levels were kept near saturation and water temperature ranged between 20.0 and $23.6^{\circ} \mathrm{C}$. The trial lasted 180 days, during which, fish were hand fed until apparent satiation (fish were given as much feed as they would consume within a 15-minute period), twice per day, six days a week (Kalinowski et al., 2015). The feed consumption in each tank was daily recorded.

\subsection{Fish performance and color measurements}

At the beginning and at the end of the feeding trial, fish were starved for $24 \mathrm{~h}$, anesthetized with tricaine methanesulfonate (MS222; Sigma, St. Louis, MO, USA) at a concentration of $100 \mathrm{mg} / \mathrm{L}$ and individually weighed. The final mean body weight of each

Table 1

Ingredients (\%) and composition of the experimental diets (\% dry matter).

\begin{tabular}{|c|c|c|c|}
\hline & \multicolumn{3}{|l|}{ Diets } \\
\hline & Ctrl & $\mathrm{A}_{50}$ & $\mathrm{~A}_{80}$ \\
\hline \multicolumn{4}{|l|}{ Ingredients (\%) } \\
\hline Fishmeal $67^{\mathrm{a}}$ & 35 & 35 & 35 \\
\hline Maize gluten ${ }^{\mathrm{b}}$ & 15 & 15 & 15 \\
\hline Fish meal $62^{c}$ & 14 & 14 & 14 \\
\hline Fish oil ${ }^{\mathrm{d}}$ & 11 & 11 & 11 \\
\hline Soybean meal $48^{\mathrm{e}}$ & 8.5 & 8.5 & 8.5 \\
\hline Wheat meal ${ }^{\mathrm{f}}$ & 8 & 8 & 8 \\
\hline Rapeseed meal $^{g}$ & 5 & 5 & 5 \\
\hline $\mathrm{SCP}^{\mathrm{h}}$ & 2.5 & 2.5 & 2.5 \\
\hline Premix ${ }^{i}$ & 1 & 1 & 1 \\
\hline Astaxanthin $(\mathrm{mg} / \mathrm{kg})^{j}$ & - & 50 & 80 \\
\hline \multicolumn{4}{|l|}{ Diet composition } \\
\hline Moisture (\%) & 9.0 & 9.0 & 9.0 \\
\hline Ash (\%) & 11.2 & 11.2 & 11.2 \\
\hline Crude fibre (\%) & 2.0 & 2.0 & 2.0 \\
\hline Crude protein (\%) & 55.0 & 55.0 & 55.0 \\
\hline Fat (\%) & 17.6 & 17.6 & 17.6 \\
\hline Gross energy (kJ/g) & 20.8 & 20.8 & 20.8 \\
\hline Calcium (\%) & 2.3 & 2.3 & 2.3 \\
\hline Phosphorus (\%) & 1.7 & 1.7 & 1.7 \\
\hline Sodium (\%) & 0.5 & 0.5 & 0.5 \\
\hline \multicolumn{4}{|c|}{${ }^{\mathrm{a}}$ Whole sardine based fishmeal from Sovapec SA, Morocco. } \\
\hline \multicolumn{4}{|c|}{ b Copam SA, Portugal. } \\
\hline \multicolumn{4}{|c|}{${ }^{\mathrm{c}}$ Tuna byproduct fishmeal from Aucosa SA, Spain. } \\
\hline \multicolumn{4}{|c|}{ d Industrias Afines SL, Spain. } \\
\hline \multicolumn{4}{|c|}{ e Non GM dehulled and defatted soybean meal, from Bunge Iberica Portugal SA, Portugal. } \\
\hline \multicolumn{4}{|c|}{${ }^{\mathrm{f}}$ Reagro, Importação e Exportação SA, Portugal. } \\
\hline \multicolumn{4}{|l|}{ g Oleocom SA, Portugal. } \\
\hline \multicolumn{4}{|c|}{ h Single Cell Protein from Corynebacterium glutamicum (Protorsan) - Ajinomoto Foods Europe SAS, France. } \\
\hline \multicolumn{4}{|c|}{${ }^{\text {i }}$ Vitamin A 5.000 I.U./kg; Vitamin D3 1.000 I.U./kg; Vitamin E 200 I.U./kg; Vitamin C 100 mg/kg; Vitamin K3 5 mg/ } \\
\hline \multicolumn{4}{|c|}{ kg; VItamin B1 4 mg/kg; Vitamin B2 10 mg/kg; Vitamin B6 5 mg/kg; Vitamin B12 $10 \mu \mathrm{g} / \mathrm{kg}$; Biothin 0.35 mg/kg; } \\
\hline \multicolumn{4}{|c|}{ Inositol 150 mg/kg; Folic acid 3 g/kg; Nicotinic acid 35 mg/kg; Panthotenic acid 15 mg/kg; CuSO 3 mg/kg; FeSO 20} \\
\hline \multicolumn{4}{|c|}{$\mathrm{mg} / \mathrm{kg} ; \mathrm{KI} 1 \mathrm{mg} / \mathrm{kg} ; \mathrm{MnO}_{2} 12 \mathrm{mg} / \mathrm{kg} ; \mathrm{Na}_{2} \mathrm{SeO}_{3} 0.15 \mathrm{mg} / \mathrm{kg} ; \mathrm{ZnO} 15 \mathrm{mg} / \mathrm{kg}$ Valouro SA, Portugal; Betafin S1 $0.4 \mathrm{~g} / \mathrm{kg}$; } \\
\hline Choline chloride $0.5 \mathrm{~g} / \mathrm{k}$ & & & \\
\hline
\end{tabular}


experimental treatment was determined by dividing the total fish weight of the three replicates by the number of fish. Specific growth rate (SGR), daily growth index (DGI), feed conversion ratio (FCR), protein efficiency ratio (PER) and the hepatosomatic index (HSI) were calculated as:

$\mathrm{SGR}=\left[\ln _{\text {average final weight }(\mathrm{g})}-\ln _{\text {average initial weight }(\mathrm{g})}\right) /$ days $] \times 100$

DGI $=\left[\right.$ final weight $(\mathrm{g})^{1 / 3}-$ initial weight $^{1 / 3}(\mathrm{~g}) /$ days $] \times 100$

$\mathrm{FCR}=$ feed intake during the whole experimental period $(\mathrm{g}) /$ gained weight during the whole experimental period $(\mathrm{g})$

PER = weight gain $(\mathrm{g}) /$ protein intake $(\mathrm{g})$ (based on the diets protein content, Table $\mathrm{S} 1)$

HSI $=$ liver weight $(\mathrm{g}) /$ fish weight $(\mathrm{g}) \times 100)$

In the current study, colorimetric analysis was done using a colorimeter (MiniScan EZ, HunterLab) calibrated on a white reference plate (with reflectance values of $L^{*}=+95.91, a^{*}=+0.09$ and $b^{*}=+2.02$ ). According to the concept of International Commission on Illumination (CIE, 1976), color is a three-dimensional characteristic of appearance consisting of a lightness attribute ( $\left.\mathrm{L}^{*}\right)$ and two chromatic attributes, hue and chroma. $\mathrm{L}^{*}$ ranges from 0 for black and 100 for white. Hue $\left(\mathrm{H}^{\circ}\right)$ is determined by the dominant wavelength and is the name of a color as found in its pure state in the spectrum. Chroma ( $\left.\mathrm{C}^{*}\right)$ refers to the saturation of a color and it is a measure of how much grey and white light is mixed in with the 'pure' focal color. The skin color parameters registered from the colorimeter were: $\mathrm{L}^{*}$ (lightness), $\mathrm{a}$ * (redness/greenness chromaticity) and $\mathrm{b}^{*}$ (yellowness/bluish chromaticity). From $\mathrm{a}^{*}$ and $\mathrm{b}^{*}$ values, hue and chroma were then calculated as $\mathrm{H}^{\circ}=\tan ^{-1}\left(\mathrm{~b}^{*} / \mathrm{a}^{*}\right)$ and $\mathrm{C}^{*}=\left(\left(\mathrm{a}^{* 2}+\mathrm{b}^{* 2}\right)^{0.5}\right)$, respectively (Boccard et al., 1981). Color measurements were taken in all fish, immediately after anesthetization. A total of three readings was taken in the caudal and pectoral regions, always on the left side of the fish.

\subsection{Analytical methods}

Twelve fish per treatment (four fish per tank) were killed in iced water, following European Directive $n^{\circ} .2010 / 63 / \mathrm{UE}$ on the protection of animals used for scientific purposes. Skin samples were collected from the left-hand side of all fish, in the front lateral zone (Kalinowski et al., 2005) for carotenoid and astaxanthin determination. The livers from nine fish per treatment (three per replicate) were excised and weighed (W), for hepatosomatic index determination (HSI, see 2.3). Samples of dorsal muscle and mesenteric fat were taken from twelve fish for subsequent analysis of tissues proximate composition (dry matter, ash, crude protein and total lipid), lipid classes and fatty acids profile. Following the excision, all tissue samples were immediately snap-frozen in liquid nitrogen and kept at $-80{ }^{\circ} \mathrm{C}$ until they were freeze dried and again stored at $-80{ }^{\circ} \mathrm{C}$ until further analysis.

\subsubsection{Tissues proximate composition}

Samples of red porgy muscle and liver were analysed following AOAC (1975) procedures: dry matter ( $105{ }^{\circ} \mathrm{C}$ to constant weight), ash $\left(550{ }^{\circ} \mathrm{C}\right.$ to constant weight), crude protein $(\mathrm{N} \times 6.25)$ by the Kjeldahl method after acid digestion and total lipids $(\mathrm{TL})$ were extracted with a chloroform-methanol mixture $(1: 2, \mathrm{v} / \mathrm{v})$, containing $0.01 \%(\mathrm{w} / \mathrm{v})$ BHT (butylated hydroxytoluene), according to Bligh and Dyer (1959). Prior to lipid and protein determinations, residual moisture was determined using a Gibertini-Eurotherm dry weight balance.

\subsubsection{Lipid classes}

Lipid classes were separated from total lipids using a silica column at atmospheric pressure. Before making the column, the silica (60 mesh, Sigma) was activated at $100{ }^{\circ} \mathrm{C}$. The column was compacted by the dichloromethane. The elution sequence, of growing polarity, followed Guckert et al. (1985) and Smith et al. (1986) procedure: first dichloromethane, then acetone and finally methanol. The fractions were dried by low nitrogen flow. These elutions allow the separation of the different lipid fraction: neutral lipids (dichloromethane; NL), phospholipids (acetone; PhL) and glycolipids (methanol; GL). PhL and GL were the polar lipids.

\subsubsection{Fatty acids profile}

Fatty acids content was determined as fatty acid methyl esters (FAME) according to the procedure of Lepage and Roy (1986) modified by Cohen et al. (1988), by gas chromatography-mass spectrometry (GC-MS). In brief, analyses were performed in a gas chromatograph (GC, Agilent HP 6890) equipped with a flame ionisation detector and a mass selective detector (Agilent 5973). The separation was performed in a polyethylene glycol capillary column (Supercolwax) with $30 \mathrm{~m}$ of length, $0.25 \mathrm{~mm}$ i.d. and $0.25 \mu \mathrm{m}$ film thickness from Supelco. The chromatographic conditions were as follows: oven initial temperature was $150{ }^{\circ} \mathrm{C}$ for 2 min; increasing 3 ${ }^{\circ} \mathrm{C} / \mathrm{min}$ to $205{ }^{\circ} \mathrm{C}$ and kept for $2 \mathrm{~min}, 3{ }^{\circ} \mathrm{C} / \mathrm{min}$ to $230{ }^{\circ} \mathrm{C}$ and $30{ }^{\circ} \mathrm{C} / \mathrm{min}$ until reaching the final temperature of $300{ }^{\circ} \mathrm{C}$ for $5 \mathrm{~min}$; transfer line temperature $260^{\circ} \mathrm{C}$; temperature detector, $270{ }^{\circ} \mathrm{C}$; split ratio, $40: 1$. Helium was used as a carrier gas with a flow rate of 1 $\mathrm{mL} / \mathrm{min}$. The FAME identification was accomplished by comparing the retention times and mass spectra fragmentation to those of known standards (Supelco 37 component FAME and mix bacterial acid methyl esters CP mix from Supelco). Four replicates were performed for each GC analysis and FAME are expressed as percentage of dry mater. The internal standard used was the heneicosanoic acid (C21:0). 


\subsubsection{Carotenoids extraction and astaxanthin determination}

Carotenoids were extracted from dried skin red porgy using dimethyl sulphoxide (DMSO) and acetone as solvents extractors. Briefly, DMSO was added to the samples and heated for $30 \mathrm{~min}$ in a water bath with a temperature between 45 and $50{ }^{\circ} \mathrm{C}$. The solutions were centrifuged at $3720 \mathrm{~g}$ for $10 \mathrm{~min}$ and the supernatant was removed. Extraction was repeated with acetone until the organic phase was devoid of color. All the supernatants were combined in a volumetric flask and used for estimation of total carotenoid and to astaxanthin determination.

The total carotenoids content was calculated using the absorbance value measured in a spectrophotometer UV at $471-477 \mathrm{~nm}$ and an extinction coefficient of $\varepsilon=2500 \mathrm{~L} / \mathrm{mol} \mathrm{cm}$ (Davies, 1976).

Astaxanthin was separated and determined from the total carotenoids extract by high performance liquid chromatography (HPLC) according Cifuentes et al. (2003) with some modifications. The HPLC apparatus consisted of an Agilent 1110 Series (Palo Alto, CA, USA), equipped with an autosampler (Agilent G1313A), quaternary pump (Agilent G1311A) and UV-vis detector (Agilent 1100 G1315B DAD). The separation was carried out using a reversed phase C18 (Phenomenex, $250 \times 4.6 \mathrm{~mm}$ ) column, in an isocratic solvent system (80:20, acetonitrile:ethyl acetate, $\mathrm{v} / \mathrm{v}$ ), at a flow rate of $1.0 \mathrm{~mL} / \mathrm{min}$ for $10 \mathrm{~min}$. Astaxanthin was detected at $477 \mathrm{~nm}$ (Davies, 1976) and identified by its time retention and absorption spectra using standard substance.

\subsection{Statistical analysis}

Statistical analyses followed reported methods (Zar, 2010). IBM SPSS Statistics 25 was the software used for all the statistical analysis performed. All data were tested for normality, using a Kolmogorov-Smirnov (whenever $n>30$ ) or Shapiro-Wilk (whenever $\mathrm{n}<30$ ) test, and for homogeneity of variance, using a Levene's test. All percentage data were arcsine transformed prior to analysis. The overall influence of dietary treatment on performance parameters (IBW, FBW, SGR, DGI, FCR and PER), HSI and tissues composition, lipid classes and fatty acid content, as well as skin carotenoid and astaxanthin content was tested by one-way ANOVA followed by a Tukey's post-hoc test. A non-parametric Kruskal-Wallis test followed by a Games-Howell post-hoc test was used instead, whenever data did not meet normality and homoscedasticity requirements. The results are presented as the mean value \pm standard deviation (SD). Significance levels were set at $\mathrm{P}<0.05$.

\section{Results}

\subsection{Fish performance}

Dietary supplementation with astaxanthin did not affect red porgy growth, as elicited from the results on final body weight, specific growth rate and daily growth index (Table S1). Feed conversion ratio, protein efficiency utilization and hepatosomatic index were also not affected by dietary astaxanthin supplementation (Table S1). However, there was a significant effect on the lipid (P $<0.01$ ) and protein $(P<0.01)$ content of the muscle, with the $A_{50} A_{80}$ group displaying a lower protein content and higher fat content when compared to the other groups (Table 2).

\subsection{Lipid metabolism}

Total lipids (TL) accounted for 40-50 \% of liver and for 88-93\% of mesenteric fat, dry matter (Fig. 1). The neutral lipids (NL) were overrepresented in mesenteric fat (62-69\%) whereas in liver a more even distribution was found between phospholipids (PhL; 41-59 $\%$ ) and neutral lipids (37-55 \%) (Fig. 1). Fish grown solely upon the $\mathrm{A}_{50}$ diet were found to have a significant lower percentage of phospholipids $(\mathrm{P}<0.01)$ and higher percentage of neutral lipids $(\mathrm{P}<0.01)$ when compared to the other groups.

Overall, the major fatty acids found in the different fractions of the liver's and mesenteric fat were palmitic acid (C16:0); oleic acid

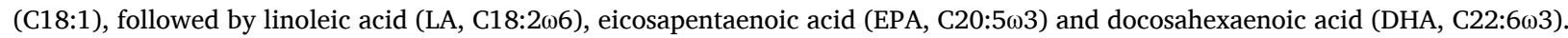

Although there were some differences on the liver's fatty acid profile among dietary treatments, there was no clear trend related with dietary supplementation with astaxanthin. Within the neutral lipids, the $\mathrm{A}_{50}$ and $\mathrm{A}_{80}$ groups had a higher percentage of myristic acid (C14:0). Conversely, the $\mathrm{A}_{50} \mathrm{~A}_{80}$ group had a higher amount of $\alpha$-linolenic acid (C18:3 $\omega 3$ ) than the Ctrl group and both the $\mathrm{A}_{50}$ and

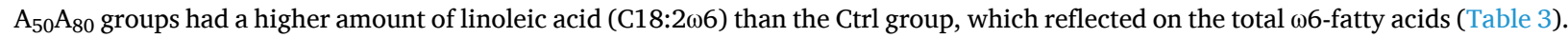
Fatty acid profile of liver's phospholipids showed that the group fed the $\mathrm{A}_{80}$ diet had a significantly higher percentage of myristic acid

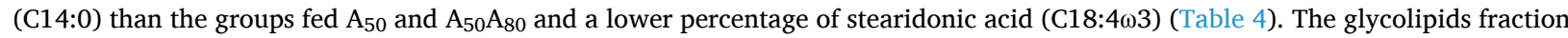

Table 2

Muscle composition (\%, dry matter) of the commercial size red porgy (P. pagrus) fed with different experimental diets.

\begin{tabular}{|c|c|c|c|c|c|}
\hline & \multicolumn{4}{|l|}{ Diets } & \multirow[b]{2}{*}{$P$-value } \\
\hline & Ctrl & $\mathrm{A}_{50}$ & $\mathrm{~A}_{80}$ & $\mathrm{~A}_{50} \mathrm{~A}_{80}$ & \\
\hline Lipids & $10.0 \pm 0.94^{b}$ & $9.48 \pm 0.81^{b}$ & $9.84 \pm 2.20^{b}$ & $14.8 \pm 1.78^{a}$ & $<0.01$ \\
\hline Protein & $86.2 \pm 3.36^{\mathrm{a}}$ & $86.9 \pm 1.80^{\mathrm{a}}$ & $89.1 \pm 2.24^{\mathrm{a}}$ & $82.9 \pm 3.20^{b}$ & $<0.01$ \\
\hline Water content & $74.1 \pm 0.95$ & $73.6 \pm 1.55$ & $74.6 \pm 1.18$ & $73.2 \pm 1.31$ & 0.45 \\
\hline Ash & $5.10 \pm 0.54$ & $6.21 \pm 0.60$ & $6.21 \pm 0.80$ & $5.14 \pm 0.47$ & 0.10 \\
\hline
\end{tabular}

Data are expressed as mean \pm SD; Different letters within the same row represent statistical differences. 

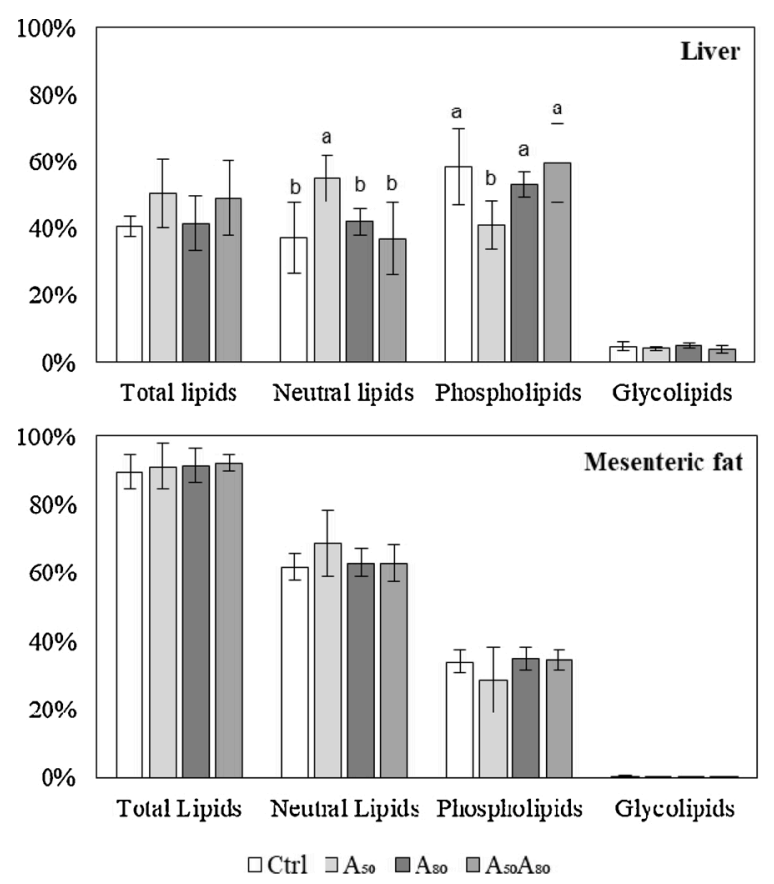

Fig. 1. Total lipids (\%, dry matter) and lipid classes (\% of total lipid) in the liver and mesenteric fat of the commercial size red porgy (P. pagrus) fed different experimental diets. Data are expressed as mean \pm SD. Different letters represent statistical differences $(P<0.05)$.

accounted for less than $5 \%$ of liver total lipids (Fig. 1). Within this fraction, the $\mathrm{A}_{50} \mathrm{~A}_{80}$ group had a higher amount of stearic acid (C18:0) than the $A_{50}$ group, which in turn presented a higher amount of $\alpha$-linolenic acid (C18:3 $\omega 3$ ) than any other group. These variations did not reflect on the total $\omega 3$-fatty acids, in which EPA and DHA were the predominant fatty acids, accounting for

Table 3

Neutral lipids fatty acids profile (\% detected) in the liver of commercial size red porgy (P. pagrus) fed with different experimental diets.

\begin{tabular}{|c|c|c|c|c|c|}
\hline \multirow[b]{2}{*}{ Fatty acids } & \multicolumn{4}{|l|}{ Diets } & \multirow[b]{2}{*}{$P$-value } \\
\hline & Ctrl & $\mathrm{A}_{50}$ & $A_{80}$ & $\mathrm{~A}_{50} \mathrm{~A}_{80}$ & \\
\hline \multicolumn{6}{|c|}{ Saturated fatty acid } \\
\hline C14:0 & $4.93 \pm 0.29^{\mathrm{b}}$ & $5.64 \pm 0.10^{\mathrm{a}}$ & $5.68 \pm 0.41^{\mathrm{a}}$ & $4.63 \pm 0.30^{b}$ & $<0.01$ \\
\hline C16:0 & $18.9 \pm 0.55$ & $19.5 \pm 1.53$ & $20.2 \pm 0.88$ & $18.6 \pm 1.83$ & 0.33 \\
\hline C18:0 & $7.99 \pm 0.48$ & $8.03 \pm 1.84$ & $8.07 \pm 0.78$ & $8.22 \pm 1.13$ & 1.00 \\
\hline Other & $1.39 \pm 0.04^{b}$ & $1.60 \pm 0.09^{\mathrm{a}}$ & $1.60 \pm 0.07^{\mathrm{a}}$ & $1.42 \pm 0.12^{b}$ & $<0.01$ \\
\hline Total & $33.2 \pm 0.92$ & $34.7 \pm 3.53$ & $35.6 \pm 1.51$ & $32.8 \pm 3.14$ & 0.30 \\
\hline \multicolumn{6}{|c|}{ Monosaturated fatty acid } \\
\hline C16:1 & $10.1 \pm 0.34$ & $10.7 \pm 1.12$ & $10.41 \pm 1.40$ & $10.2 \pm 1.08$ & 0.81 \\
\hline C18:1 & $19.3 \pm 0.37$ & $18.7 \pm 0.72$ & $19.6 \pm 1.56$ & $20.2 \pm 1.07$ & 0.29 \\
\hline C20:1 & $2.76 \pm 0.12$ & $3.37 \pm 0.64$ & $3.39 \pm 0.13$ & $2.96 \pm 0.41$ & 0.15 \\
\hline Other & $2.17 \pm 0.21$ & $2.79 \pm 0.70$ & $2.83 \pm 0.21$ & $2.12 \pm 0.55$ & 0.11 \\
\hline Total & $34.4 \pm 0.77$ & $35.6 \pm 0.93$ & $36.2 \pm 2.68$ & $35.4 \pm 1.00$ & 0.31 \\
\hline \multicolumn{6}{|c|}{ Polyunsaturated fatty acid } \\
\hline 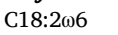 & $6.48 \pm 0.02^{b}$ & $7.31 \pm 0.38^{\mathrm{a}}$ & $6.85 \pm 0.17^{\mathrm{ab}}$ & $7.16 \pm 0.04^{\mathrm{a}}$ & 0.01 \\
\hline $\mathrm{C} 18: 3 \omega 3$ & $0.86 \pm 0.05^{b}$ & $0.90 \pm 0.02^{\mathrm{ab}}$ & $0.88 \pm 0.02^{\mathrm{ab}}$ & $0.94 \pm 0.02^{\mathrm{a}}$ & 0.02 \\
\hline $\mathrm{C} 18: 4 \omega 3$ & $1.35 \pm 0.10$ & $1.25 \pm 0.22$ & $1.18 \pm 0.14$ & $1.25 \pm 0.12$ & 0.55 \\
\hline $\mathrm{C} 20: 3 \omega 6$ & $0.68 \pm 0.02$ & $0.64 \pm 0.14$ & $0.65 \pm 0.12$ & $0.69 \pm 0.21$ & 0.97 \\
\hline $\mathrm{C} 20: 4 \omega 6$ & $0.88 \pm 0.04$ & $0.79 \pm 0.18$ & $0.74 \pm 0.04$ & $0.96 \pm 0.21$ & 0.20 \\
\hline $\mathrm{C} 20: 5 \omega 3$ & $7.80 \pm 0.43$ & $6.38 \pm 1.50$ & $6.23 \pm 1.14$ & $7.36 \pm 0.96$ & 0.18 \\
\hline $\mathrm{C} 22: 5 \omega 3$ & $2.91 \pm 0.16$ & $2.36 \pm 0.72$ & $2.17 \pm 0.22$ & $2.78 \pm 0.67$ & 0.28 \\
\hline $\mathrm{C} 22: 6 \omega 3$ & $8.94 \pm 0.52$ & $7.44 \pm 1.64$ & $7.14 \pm 1.96$ & $8.19 \pm 1.55$ & 0.20 \\
\hline Other & $2.54 \pm 0.15$ & $2.64 \pm 0.45$ & $2.42 \pm 0.07$ & $2.43 \pm 0.28$ & 0.78 \\
\hline Total & $32.4 \pm 1.23$ & $29.7 \pm 4.44$ & $28.2 \pm 3.43$ & $31.8 \pm 3.82$ & 0.25 \\
\hline Total $\omega 3$ & $22.4 \pm 1.06$ & $18.8 \pm 4.11$ & $18.0 \pm 3.44$ & $21.0 \pm 3.31$ & 0.19 \\
\hline Total $\omega 6$ & $8.04 \pm 0.19^{b}$ & $8.74 \pm 0.06^{a}$ & $8.25 \pm 0.05^{\mathrm{ab}}$ & $8.81 \pm 0.31^{\mathrm{a}}$ & $<0.01$ \\
\hline$\omega 3 / \omega 6$ & $2.78 \pm 012$ & $2.16 \pm 0.49$ & $2.19 \pm 0.42$ & $2.38 \pm 0.29$ & 0.02 \\
\hline DHA/EPA & $1.15 \pm 0.07$ & $1.17 \pm 0.02$ & $1.13 \pm 0.11$ & $1.11 \pm 0.07$ & 0.82 \\
\hline EPA/ARA & $8.91 \pm 0.21$ & $8.08 \pm 0.18$ & $8.34 \pm 1.14$ & $7.77 \pm 0.75$ & 0.17 \\
\hline
\end{tabular}

Data are expressed as mean $\pm \mathrm{SD}$; Different letters within the same row represent statistical differences $(\mathrm{P}<0.05)$. 
approximately 7 and $16 \%$, respectively (Table 5).

Regarding the mesenteric fat, there was no significant effect of dietary astaxanthin supplementation on the lipid classes. Although minor differences in the content of some fatty acids were detected in all lipid classes, there was no obvious relation with astaxanthin supplementation (Tables 6-8). Within the neutral lipids the $A_{80}$ group presented higher amounts of palmitic acid (16:0) than any other group, reflecting on total SFA (Table 6). As for the PUFA, results showed that the $\mathrm{A}_{50} \mathrm{~A}_{80}$ group had a higher amount of linoleic acid

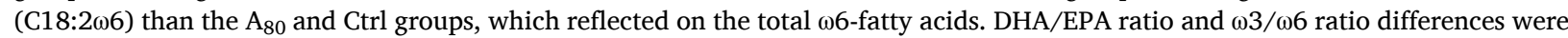
explained by the fact that the $A_{80}$ group had higher EPA content than any other group, while the $A_{50} A_{80}$ had the lowest EPA levels (Table 6). In the phospholipids class, the $A_{80}$ group had a higher amount of palmitic (16:0) and stearic acids (18:0) and a lower amount of oleic (C18:1) and eicosenoic (C20:1) acids when compared to the $\mathrm{A}_{50} \mathrm{~A}_{80}$ group, reflecting on the total saturated fatty acids (SFA) and the mono-unsaturated fatty acids (MUFA) (Table 7). Total $\omega 6$-fatty acids was significantly higher in fish fed the $A_{50} A_{80}$ than in those fed the $\mathrm{Ctrl}$ or $\mathrm{A}_{80}$ diets, which reflected on $\omega 3 / \omega 6$ ratio that was significantly higher in fish fed the Ctrl and $\mathrm{A}_{80}$ diets as compared to those grown upon the $\mathrm{A}_{50} \mathrm{~A}_{80}$ diet (Table 7). Within the diminutive glycolipids fraction (less than $0.46 \%$ of mesenteric fat total lipids) (Fig. 1), changes in fatty acids profile did not reveal a clear response to dietary astaxanthin supplementation (Table 8).

\subsection{Skin color and carotenoid accumulation}

Dietary astaxanthin supplementation had an effect on color of both the pectoral and caudal regions of red porgy, affecting the recorded and calculated values of the parameters used to describe skin color of red porgy (Table 9; Fig. 2). The supplementation with synthetic astaxanthin increased redness $\left(a^{*}\right)$ in both pectoral and caudal regions. Although no significant differences were observed in the yellowness $\left(\mathrm{b}^{*}\right)$, hue values decreased in all the diet groups, making their skin look less yellowish than the fish fed the Ctrl diet (70.09 \pm 4.71 in the pectoral region and 67.42 \pm 3.22 in the caudal region, Fig. 2), but still yellowish (56-60 and 53-58 in the pectoral and caudal regions, respectively). Chroma results showed that the $\mathrm{A}_{80}$ and $\mathrm{A}_{50} \mathrm{~A}_{80}$ groups displayed a brighter color in the pectoral region than the Ctrl group, while $A_{50}$ displayed intermediate brightness. The $A_{80}$ and $A_{50} A_{80}$ group displayed a significantly brighter color in the caudal region than the Ctrl group, while $A_{50}$ groups displayed intermediate values (Fig. 2). Significant differences were also found in the astaxanthin content, which increased with increasing dietary astaxanthin (Fig. 3). However, these differences were not clearly reflected in the total carotenoids content measured in the skin of red porgy, which was highly variable and without significant differences among groups (Fig. 3).

Table 4

Phospholipids fatty acids profile (\% detected) in the liver of commercial size red porgy (P. pagrus) fed with different experimental diets.

\begin{tabular}{|c|c|c|c|c|c|}
\hline & \multicolumn{4}{|l|}{ Diets } & \multirow[b]{2}{*}{ P-value } \\
\hline & Ctrl & $\mathrm{A}_{50}$ & $\mathrm{~A}_{80}$ & $\mathrm{~A}_{50} \mathrm{~A}_{80}$ & \\
\hline \multicolumn{6}{|c|}{ Saturated fatty acid } \\
\hline C14:0 & $8.13 \pm 0.76^{\mathrm{ab}}$ & $7.40 \pm 0.21^{b}$ & $9.60 \pm 1.26^{\mathrm{a}}$ & $6.76 \pm 1.30^{b}$ & 0.03 \\
\hline C16:0 & $30.2 \pm 0.66$ & $24.8 \pm 3.61$ & $32.9 \pm 2.53$ & $25.8 \pm 7.78$ & 0.08 \\
\hline C18:0 & $9.35 \pm 1.25$ & $8.08 \pm 3.20$ & $9.59 \pm 0.66$ & $7.61 \pm 1.66$ & 0.31 \\
\hline Other & $1.82 \pm 0.11$ & $1.82 \pm 0.20$ & $2.05 \pm 0.43$ & $1.62 \pm 0.21$ & 0.42 \\
\hline Total & $49.6 \pm 0.38$ & $42.1 \pm 6.97$ & $54.1 \pm 4.41$ & $41.8 \pm 10.9$ & 0.07 \\
\hline \multicolumn{6}{|c|}{ Monosaturated fatty acid } \\
\hline C16:1 & $12.6 \pm 1.25$ & $13.0 \pm 1.34$ & $13.2 \pm 1.02$ & $12.1 \pm 0.38$ & 0.49 \\
\hline C18:1 & $26.0 \pm 1.24$ & $21.2 \pm 2.22$ & $23.9 \pm 1.64$ & $23.9 \pm 5.14$ & 0.17 \\
\hline C20:1 & $2.92 \pm 0.37$ & $2.94 \pm 0.78$ & $3.19 \pm 0.11$ & $2.70 \pm 0.75$ & 0.79 \\
\hline Other & $2.54 \pm 0.92$ & $2.28 \pm 0.66$ & $2.56 \pm 0.23$ & $2.04 \pm 0.70$ & 0.56 \\
\hline Total & $44.0 \pm 2.71$ & $39.4 \pm 2.44$ & $42.8 \pm 2.83$ & $40.7 \pm 6.20$ & 0.36 \\
\hline \multicolumn{6}{|c|}{ Polyunsaturated fatty acid } \\
\hline $\mathrm{C} 18: 2 \omega 6$ & $1.84 \pm 0.54$ & $5.73 \pm 0.92$ & $1.14 \pm 0.84$ & $3.95 \pm 3.68$ & 0.11 \\
\hline $\mathrm{C} 18: 3 \omega 3$ & $0.41 \pm 0.04$ & $0.71 \pm 0.20$ & $0.33 \pm 0.08$ & $0.67 \pm 0.44$ & 0.15 \\
\hline $\mathrm{C} 18: 4 \omega 3$ & $0.65 \pm 0.26^{\mathrm{ab}}$ & $0.99 \pm 0.49^{\mathrm{ab}}$ & $0.44 \pm 0.08^{b}$ & $1.20 \pm 0.42^{\mathrm{a}}$ & 0.03 \\
\hline $\mathrm{C} 20: 3 \omega 6$ & $0.21 \pm 0.01$ & $0.64 \pm 0.51$ & $0.00 \pm 0.00$ & $0.55 \pm 0.64$ & 0.08 \\
\hline $\mathrm{C} 20: 4 \omega 6$ & $0.15 \pm 0.08$ & $0.51 \pm 0.29$ & $0.08 \pm 0.07$ & $0.58 \pm 0.59$ & 0.09 \\
\hline $\mathrm{C} 20: 5 \omega 3$ & $1.11 \pm 0.98$ & $3.74 \pm 2.63$ & $0.25 \pm 0.24$ & $4.21 \pm 4.80$ & 0.20 \\
\hline $\mathrm{C} 22: 5 \omega 3$ & $0.32 \pm 0.29$ & $1.22 \pm 0.85$ & $0.06 \pm 0.08$ & $1.43 \pm 1.50$ & 0.09 \\
\hline $\mathrm{C} 22: 6 \omega 3$ & $0.86 \pm 0.55$ & $2.60 \pm 1.86$ & $0.19 \pm 0.14$ & $3.14 \pm 3.47$ & 0.10 \\
\hline Other & $0.87 \pm 0.22$ & $2.34 \pm 1.07$ & $0.54 \pm 0.14$ & $1.84 \pm 1.50$ & 0.07 \\
\hline Total & $6.43 \pm 2.94$ & $18.5 \pm 8.79$ & $3.04 \pm 1.77$ & $17.6 \pm 17.04$ & 0.11 \\
\hline Total $\omega 3$ & $3.48 \pm 2.17$ & $9.67 \pm 6.14$ & $1.36 \pm 0.66$ & $11.0 \pm 10.93$ & 0.20 \\
\hline Total $\omega 6$ & $2.21 \pm 0.62$ & $6.88 \pm 1.71$ & $1.22 \pm 0.91$ & $5.08 \pm 4.91$ & 0.11 \\
\hline$\omega 3 / \omega 6$ & $1.46 \pm 0.58$ & $1.30 \pm 0.57$ & $1.40 \pm 0.59$ & $1.99 \pm 0.24$ & 0.28 \\
\hline DHA/EPA & $1.08 \pm 0.46$ & $0.69 \pm 0.02$ & $1.24 \pm 0.72$ & $1.60 \pm 1.11$ & 0.20 \\
\hline EPA/ARA & $6.03 \pm 3.10$ & $6.77 \pm 1.36$ & $2.59 \pm 1.02$ & $4.20 \pm 3.98$ & 0.14 \\
\hline
\end{tabular}

Data are expressed as mean $\pm \mathrm{SD}$; Different letters within the same row represent statistical differences $(\mathrm{P}<0.05)$. 
Table 5

Glycolipids fatty acids profile (\% detected) in the liver of commercial size red porgy ( $P$. pagrus) fed with different experimental diets.

\begin{tabular}{|c|c|c|c|c|c|}
\hline \multirow[b]{2}{*}{ Fatty acids } & \multicolumn{4}{|l|}{ Diets } & \multirow[b]{2}{*}{$P$-value } \\
\hline & Ctrl & A50 & A80 & A5080 & \\
\hline \multicolumn{6}{|c|}{ Saturated fatty acid } \\
\hline $\mathrm{C} 14: 0$ & $2.80 \pm 0.51$ & $3.42 \pm 1.19$ & $3.43 \pm 0.69$ & $2.78 \pm 0.90$ & 0.53 \\
\hline $\mathrm{C} 16: 0$ & $24.3 \pm 2.49$ & $26.6 \pm 1.07$ & $28.4 \pm 2.68$ & $25.0 \pm 4.60$ & 0.27 \\
\hline C18:0 & $6.45 \pm 0.76^{\mathrm{ab}}$ & $6.37 \pm 0.27^{b}$ & $6.62 \pm 0.78^{\mathrm{ab}}$ & $7.66 \pm 0.41^{\mathrm{a}}$ & 0.03 \\
\hline Other & $1.53 \pm 0.03$ & $1.75 \pm 0.04$ & $1.62 \pm 0.22$ & $1.69 \pm 0.11$ & 0.24 \\
\hline Total & $35.1 \pm 2.49$ & $38.1 \pm 1.95$ & $40.0 \pm 3.82$ & $37.1 \pm 5.86$ & 0.44 \\
\hline \multicolumn{6}{|c|}{ Monosaturated fatty acid } \\
\hline C16:1 & $5.62 \pm 1.52$ & $6.72 \pm 1.53$ & $7.24 \pm 1.93$ & $5.73 \pm 1.19$ & 0.46 \\
\hline C18:1 & $15.1 \pm 2.66$ & $17.1 \pm 4.39$ & $18.8 \pm 3.76$ & $15.7 \pm 3.84$ & 0.36 \\
\hline C20:1 & $1.31 \pm 0.25$ & $1.97 \pm 0.80$ & $1.94 \pm 0.09$ & $1.40 \pm 0.18$ & 0.13 \\
\hline Other & $2.30 \pm 0.55$ & $3.41 \pm 0.94$ & $2.74 \pm 0.17$ & $2.48 \pm 0.61$ & 0.48 \\
\hline Total & $24.4 \pm 4.90$ & $29.2 \pm 7.64$ & $30.8 \pm 5.47$ & $25.3 \pm 5.78$ & 0.33 \\
\hline \multicolumn{6}{|c|}{ Polyunsaturated fatty acid } \\
\hline $\mathrm{C} 18: 2 \omega 6$ & $3.59 \pm 0.50$ & $4.65 \pm 1.20$ & $4.24 \pm 0.25$ & $3.98 \pm 0.36$ & 0.30 \\
\hline $\mathrm{C} 18: 3 \omega 3$ & $1.05 \pm 0.14^{\mathrm{b}}$ & $1.42 \pm 0.20^{\mathrm{a}}$ & $0.91 \pm 0.07^{\mathrm{b}}$ & $1.13 \pm 0.07^{\mathrm{b}}$ & $<0.01$ \\
\hline $\mathrm{C} 18: 4 \omega 3$ & $1.32 \pm 0.17$ & $1.62 \pm 0.32$ & $1.58 \pm 0.39$ & $1.67 \pm 0.27$ & 0.25 \\
\hline $\mathrm{C} 20: 3 \omega 6$ & $1.55 \pm 0.46$ & $1.28 \pm 0.44$ & $1.01 \pm 0.29$ & $1.61 \pm 0.44$ & 0.20 \\
\hline 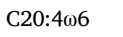 & $0.58 \pm 0.07$ & $0.49 \pm 0.06$ & $0.41 \pm 0.13$ & $0.60 \pm 0.14$ & 0.15 \\
\hline $\mathrm{C} 20: 5 \omega 3$ & $7.77 \pm 0.99$ & $6.36 \pm 2.74$ & $5.48 \pm 1.81$ & $7.06 \pm 2.11$ & 0.38 \\
\hline $\mathrm{C} 22: 5 \omega 3$ & $2.48 \pm 0.26$ & $1.75 \pm 0.68$ & $1.73 \pm 0.38$ & $2.16 \pm 0.68$ & 0.15 \\
\hline $\mathrm{C} 22: 6 \omega 3$ & $20.8 \pm 6.37$ & $13.6 \pm 7.35$ & $12.4 \pm 5.90$ & $17.6 \pm 8.78$ & 0.36 \\
\hline Other & $1.38 \pm 0.19^{b}$ & $1.54 \pm 0.21^{\mathrm{ab}}$ & $1.40 \pm 0.13^{b}$ & $1.80 \pm 0.14^{\mathrm{a}}$ & 0.02 \\
\hline Total & $40.6 \pm 7.21$ & $32.7 \pm 9.59$ & $29.2 \pm 8.26$ & $37.6 \pm 11.52$ & 0.36 \\
\hline Total $\omega 3$ & $33.8 \pm 7.40$ & $25.1 \pm 10.5$ & $22.4 \pm 7.78$ & $30.0 \pm 11.3$ & 0.31 \\
\hline Total $\omega 6$ & $5.72 \pm 0.44$ & $6.42 \pm 0.70$ & $5.66 \pm 0.53$ & $6.19 \pm 0.29$ & 0.26 \\
\hline$\omega 3 / \omega 6$ & $5.94 \pm 1.43$ & $4.07 \pm 2.07$ & $3.91 \pm 1.08$ & $4.81 \pm 1.67$ & 0.30 \\
\hline DHA/EPA & $2.64 \pm 0.52$ & $2.05 \pm 0.28$ & $2.17 \pm 0.36$ & $2.38 \pm 0.54$ & 0.21 \\
\hline EPA/ARA & $13.4 \pm 0.45$ & $12.6 \pm 4.17$ & $13.6 \pm 1.75$ & $11.7 \pm 1.16$ & 0.56 \\
\hline
\end{tabular}

Data are expressed as mean $\pm \mathrm{SD}$; Different letters within the same row represent statistical differences $(\mathrm{P}<0.05)$.

Table 6

Neutral lipids fatty acids profile (\% detected) in the mesenteric fat of commercial size red porgy (P. pagrus) fed with different experimental diets.

\begin{tabular}{|c|c|c|c|c|c|}
\hline \multirow[b]{2}{*}{ Fatty acids } & \multicolumn{4}{|l|}{ Diets } & \multirow[b]{2}{*}{$P$-value } \\
\hline & Ctrl & A50 & A80 & A5080 & \\
\hline \multicolumn{6}{|c|}{ Saturated fatty acid } \\
\hline C14:0 & $5.51 \pm 0.14$ & $5.42 \pm 0.27$ & $5.65 \pm 0.14$ & $5.38 \pm 0.15$ & 0.41 \\
\hline C16:0 & $16.8 \pm 0.16^{b}$ & $16.4 \pm 0.06^{c}$ & $17.8 \pm 0.04^{\mathrm{a}}$ & $16.2 \pm 0.36^{b c}$ & 0.01 \\
\hline C18:0 & $6.01 \pm 0.37^{\mathrm{a}}$ & $6.09 \pm 0.52^{\mathrm{a}}$ & $6.71 \pm 0.26^{\mathrm{a}}$ & $4.54 \pm 0.52^{b}$ & $<0.01$ \\
\hline Other & $1.15 \pm 0.12^{b}$ & $1.21 \pm 0.14^{\mathrm{b}}$ & $1.25 \pm 0.10^{b}$ & $1.97 \pm 0.22^{\mathrm{a}}$ & $<0.01$ \\
\hline Total & $29.4 \pm 0.29^{b}$ & $29.1 \pm 0.92^{b}$ & $31.4 \pm 0.07^{a}$ & $28.1 \pm 0.77^{b}$ & $<0.01$ \\
\hline \multicolumn{6}{|c|}{ Monosaturated fatty acid } \\
\hline C16:1 & $8.94 \pm 0.16$ & $8.86 \pm 0.28$ & $9.01 \pm 0.11$ & $8.62 \pm 0.24$ & 0.17 \\
\hline C18:1 & $18.2 \pm 0.54$ & $18.1 \pm 1.17$ & $17.7 \pm 0.05$ & $19.7 \pm 0.69$ & 0.04 \\
\hline $\mathrm{C} 20: 1$ & $3.17 \pm 0.17^{\mathrm{ab}}$ & $3.42 \pm 0.17^{\mathrm{a}}$ & $2.86 \pm 0.00^{b}$ & $3.25 \pm 0.02^{\mathrm{a}}$ & 0.04 \\
\hline Other & $2.33 \pm 0.16^{\mathrm{ab}}$ & $2.67 \pm 0.19^{\mathrm{a}}$ & $2.01 \pm 0.08^{b}$ & $2.64 \pm 0.20^{\mathrm{a}}$ & $<0.01$ \\
\hline Total & $32.6 \pm 0.89$ & $33.1 \pm 1.26$ & $31.6 \pm 0.25$ & $34.2 \pm 0.89$ & 0.06 \\
\hline \multicolumn{6}{|c|}{ Polyunsaturated fatty acid } \\
\hline $\mathrm{C} 18: 2 \omega 6$ & $7.22 \pm 0.05^{b}$ & $7.32 \pm 0.36^{\mathrm{ab}}$ & $6.84 \pm 0.08^{b}$ & $7.90 \pm 0.16^{\mathrm{a}}$ & 0.02 \\
\hline $\mathrm{C} 18: 3 \omega 3$ & $1.09 \pm 0.03$ & $1.09 \pm 0.06$ & $1.02 \pm 0.06$ & $1.15 \pm 0.09$ & 0.21 \\
\hline $\mathrm{C} 18: 4 \omega 3$ & $1.85 \pm 0.02$ & $1.81 \pm 0.07$ & $1.91 \pm 0.04$ & $1.85 \pm 0.05$ & 0.23 \\
\hline $\mathrm{C} 20: 3 \omega 6$ & $0.19 \pm 0.01$ & $0.19 \pm 0.01$ & $0.18 \pm 0.00$ & $0.20 \pm 0.01$ & 0.31 \\
\hline $\mathrm{C} 20: 4 \omega 6$ & $0.09 \pm 0.00$ & $0.12 \pm 0.03$ & $0.09 \pm 0.00$ & $0.09 \pm 0.01$ & 0.06 \\
\hline $\mathrm{C} 20: 5 \omega 3$ & $10.3 \pm 0.20^{\mathrm{abc}}$ & $10.4 \pm 0.03^{b}$ & $10.7 \pm 0.02^{\mathrm{a}}$ & $10.0 \pm 0.09^{c}$ & 0.02 \\
\hline $\mathrm{C} 22: 5 \omega 3$ & $2.77 \pm 0.12$ & $2.79 \pm 0.05$ & $2.50 \pm 0.03$ & $2.55 \pm 0.18$ & 0.10 \\
\hline $\mathrm{C} 22: 6 \omega 3$ & $10.0 \pm 0.38$ & $9.99 \pm 0.22$ & $9.67 \pm 0.04$ & $10.1 \pm 0.35$ & 0.48 \\
\hline Other & $3.41 \pm 0.04$ & $3.14 \pm 0.26$ & $3.14 \pm 0.24$ & $2.94 \pm 0.35$ & 0.13 \\
\hline Total & $37.9 \pm 0.69$ & $37.8 \pm 0.41$ & $37.0 \pm 0.32$ & $37.8 \pm 0.26$ & 0.18 \\
\hline Total $\omega 3$ & $27.3 \pm 0.74$ & $27.3 \pm 0.24$ & $27.0 \pm 0.00$ & $26.9 \pm 0.30$ & 0.26 \\
\hline Total $\omega 6$ & $7.50 \pm 0.05^{b}$ & $7.63 \pm 0.38^{a b}$ & $7.11 \pm 0.08^{b}$ & $8.19 \pm 0.16^{\mathrm{a}}$ & 0.02 \\
\hline$\omega 3 / \omega 6$ & $3.64 \pm 0.12^{a}$ & $3.59 \pm 0.16^{a b}$ & $3.80 \pm 0.04^{\mathrm{a}}$ & $3.28 \pm 0.09^{b}$ & 0.01 \\
\hline DHA/EPA & $0.97 \pm 0.03^{\mathrm{ab}}$ & $0.97 \pm 0.02^{\mathrm{ab}}$ & $0.90 \pm 0.00^{b}$ & $1.01 \pm 0.04^{\mathrm{a}}$ & 0.02 \\
\hline EPA/ARA & $121 \pm 6.37$ & $92.0 \pm 20.38$ & $120.0 \pm 1.66$ & $109 \pm 9.97$ & 0.05 \\
\hline
\end{tabular}

Data are expressed as mean $\pm \mathrm{SD}$; Different letters within the same row represent statistical differences $(\mathrm{P}<0.05)$. 
Table 7

Phospholipids fatty acids profile (\% detected) in the mesenteric fat of the commercial size red porgy (P. pagrus) fed with different experimental diets.

\begin{tabular}{|c|c|c|c|c|c|}
\hline \multirow[b]{2}{*}{ Fatty acids } & \multicolumn{4}{|l|}{ Diets } & \multirow[b]{2}{*}{ P-value } \\
\hline & Ctrl & A50 & A80 & A5080 & \\
\hline \multicolumn{6}{|c|}{ Saturated fatty acid } \\
\hline $\mathrm{C} 14: 0$ & $6.64 \pm 0.20$ & $7.24 \pm 0.59$ & $6.76 \pm 0.11$ & $6.27 \pm 0.50$ & 0.07 \\
\hline $\mathrm{C} 16: 0$ & $18.6 \pm 0.14^{\mathrm{ab}}$ & $18.8 \pm 0.58^{\mathrm{ab}}$ & $19.7 \pm 0.48^{\mathrm{a}}$ & $18.1 \pm 0.54^{b}$ & 0.02 \\
\hline C18:0 & $5.57 \pm 0.87^{\mathrm{ab}}$ & $5.02 \pm 0.67^{\mathrm{ab}}$ & $6.70 \pm 1.20^{\mathrm{a}}$ & $4.35 \pm 0.39^{b}$ & 0.02 \\
\hline Other & $1.29 \pm 0.14^{\mathrm{b}}$ & $1.39 \pm 0.12^{b}$ & $1.38 \pm 0.04^{b}$ & $2.00 \pm 0.11^{\mathrm{a}}$ & $<0.01$ \\
\hline Total & $32.1 \pm 0.99^{b}$ & $32.4 \pm 0.74^{a b}$ & $34.5 \pm 1.55^{a}$ & $30.7 \pm 0.69^{b}$ & $<0.01$ \\
\hline \multicolumn{6}{|c|}{ Monosaturated fatty acid } \\
\hline C16:1 & $9.66 \pm 0.15^{\mathrm{ab}}$ & $10.1 \pm 0.25^{\mathrm{a}}$ & $9.64 \pm 0.08^{\mathrm{ab}}$ & $9.14 \pm 0.40^{b}$ & $<0.01$ \\
\hline C18:1 & $18.4 \pm 0.77^{\mathrm{ab}}$ & $18.4 \pm 0.56^{\mathrm{ab}}$ & $17.6 \pm 0.66^{\mathrm{b}}$ & $20.4 \pm 1.32^{\mathrm{a}}$ & 0.02 \\
\hline $\mathrm{C} 20: 1$ & $2.87 \pm 0.07^{\mathrm{ab}}$ & $2.88 \pm 0.12^{\mathrm{ab}}$ & $2.59 \pm 0.09^{b}$ & $3.30 \pm 0.43^{\mathrm{a}}$ & 0.05 \\
\hline Other & $1.93 \pm 0.05$ & $1.88 \pm 0.22$ & $1.68 \pm 0.10$ & $2.23 \pm 0.36$ & 0.09 \\
\hline Total & $32.9 \pm 0.86^{a b}$ & $33.2 \pm 0.40^{a b}$ & $31.5 \pm 0.54^{b}$ & $35.1 \pm 1.76^{a}$ & 0.02 \\
\hline \multicolumn{6}{|c|}{ Polyunsaturated fatty acid } \\
\hline $\mathrm{C} 18: 2 \omega 6$ & $7.19 \pm 0.07^{\mathrm{ab}}$ & $7.20 \pm 0.44^{\mathrm{ab}}$ & $6.75 \pm 0.10^{b}$ & $7.79 \pm 0.24^{\mathrm{a}}$ & 0.04 \\
\hline $\mathrm{C} 18: 3 \omega 3$ & $1.15 \pm 0.04$ & $1.16 \pm 0.05$ & $1.07 \pm 0.04$ & $1.17 \pm 0.20$ & 0.75 \\
\hline $\mathrm{C} 18: 4 \omega 3$ & $1.94 \pm 0.08$ & $2.03 \pm 0.11$ & $1.99 \pm 0.11$ & $1.91 \pm 0.29$ & 0.76 \\
\hline $\mathrm{C} 20: 3 \omega 6$ & $0.17 \pm 0.00$ & $0.18 \pm 0.03$ & $0.21 \pm 0.06$ & $0.17 \pm 0.02$ & 0.76 \\
\hline $\mathrm{C} 20: 4 \omega 6$ & $0.09 \pm 0.00^{b}$ & $0.12 \pm 0.03^{a b}$ & $0.10 \pm 0.00^{\mathrm{a}}$ & $0.09 \pm 0.00^{b}$ & 0.02 \\
\hline $\mathrm{C} 20: 5 \omega 3$ & $10.1 \pm 0.02$ & $10.4 \pm 0.36$ & $10.2 \pm 0.09$ & $9.60 \pm 0.52$ & 0.16 \\
\hline $\mathrm{C} 22: 5 \omega 3$ & $2.47 \pm 0.10$ & $2.34 \pm 0.13$ & $2.25 \pm 0.00$ & $2.31 \pm 0.22$ & 0.35 \\
\hline $\mathrm{C} 22: 6 \omega 3$ & $7.12 \pm 0.21$ & $6.05 \pm 0.99$ & $6.91 \pm 0.33$ & $7.16 \pm 0.47$ & 0.18 \\
\hline Other & $3.86 \pm 0.14$ & $3.93 \pm 0.43$ & $3.54 \pm 0.25$ & $3.12 \pm 0.67$ & 0.14 \\
\hline Total & $35.0 \pm 0.22$ & $34.3 \pm 0.87$ & $34.0 \pm 1.01$ & $34.2 \pm 1.81$ & 0.68 \\
\hline Total $\omega 3$ & $24.0 \pm 0.24$ & $23.2 \pm 0.84$ & $23.7 \pm 0.59$ & $23.3 \pm 1.08$ & 0.48 \\
\hline Total $\omega 6$ & $7.45 \pm 0.08^{b}$ & $7.50 \pm 0.49^{\mathrm{ab}}$ & $7.06 \pm 0.16^{b}$ & $8.05 \pm 0.26^{\mathrm{a}}$ & 0.05 \\
\hline$\omega 3 / \omega 6$ & $3.23 \pm 0.06^{\mathrm{a}}$ & $3.10 \pm 0.12^{\mathrm{ab}}$ & $3.36 \pm 0.01^{a}$ & $2.89 \pm 0.05^{b}$ & 0.01 \\
\hline DHA/EPA & $0.71 \pm 0.02$ & $0.59 \pm 0.11$ & $0.68 \pm 0.03$ & $0.78 \pm 0.08$ & 0.14 \\
\hline EPA/ARA & $118 \pm 2.99$ & $93.4 \pm 25.7$ & $102 \pm 0.57$ & $105 \pm 6.80$ & 0.12 \\
\hline
\end{tabular}

Data are expressed as mean $\pm \mathrm{SD}$; Different letters within the same row represent statistical differences $(\mathrm{P}<0.05)$.

Table 8

Glycolipids fatty acids profile (\% detected) in the mesenteric fat of commercial size red porgy (P. pagrus) fed with different experimental diets.

\begin{tabular}{|c|c|c|c|c|c|}
\hline \multirow[b]{2}{*}{ Fatty acids (\%) } & \multicolumn{4}{|l|}{ Diets } & \multirow[b]{2}{*}{$P$-value } \\
\hline & Ctrl & A50 & A80 & A5080 & \\
\hline \multicolumn{6}{|c|}{ Saturated fatty acid } \\
\hline C14:0 & $5.09 \pm 0.39$ & $4.40 \pm 0.15$ & $4.96 \pm 0.40$ & $5.37 \pm 0.83$ & 0.09 \\
\hline $\mathrm{C} 16: 0$ & $19.0 \pm 0.58^{a}$ & $15.7 \pm 1.92^{b}$ & $17.9 \pm 0.77^{\mathrm{ab}}$ & $18.6 \pm 0.66^{\mathrm{a}}$ & 0.01 \\
\hline C18:0 & $5.96 \pm 0.32^{\mathrm{a}}$ & $5.57 \pm 0.34^{\mathrm{ab}}$ & $5.03 \pm 0.10^{b}$ & $6.11 \pm 0.40^{\mathrm{a}}$ & 0.02 \\
\hline Other & $2.19 \pm 0.20^{\mathrm{a}}$ & $2.02 \pm 0.12^{\mathrm{a}}$ & $1.44 \pm 0.04^{b}$ & $1.49 \pm 0.03^{b}$ & 0.02 \\
\hline Total & $32.2 \pm 1.04^{a}$ & $27.7 \pm 1.51^{c}$ & $29.2 \pm 1.31^{b c}$ & $31.6 \pm 0.85^{a b}$ & $<0.01$ \\
\hline \multicolumn{6}{|c|}{ Monosaturated fatty acid } \\
\hline C16:1 & $7.09 \pm 0.25$ & $6.23 \pm 0.84$ & $7.37 \pm 0.23$ & $7.13 \pm 0.39$ & 0.08 \\
\hline C18:1 & $18.1 \pm 1.10$ & $16.8 \pm 0.56$ & $18.7 \pm 0.66$ & $18.3 \pm 0.52$ & 0.06 \\
\hline C20:1 & $1.99 \pm 0.31$ & $1.88 \pm 0.10$ & $1.87 \pm 0.03$ & $2.06 \pm 0.22$ & 0.62 \\
\hline Other & $3.00 \pm 0.38$ & $3.77 \pm 0.34$ & $3.20 \pm 0.09$ & $3.05 \pm 0.11$ & 0.10 \\
\hline Total & $30.2 \pm 1.87$ & $28.7 \pm 1.36$ & $31.2 \pm 0.55$ & $30.6 \pm 0.72$ & 0.21 \\
\hline \multicolumn{6}{|c|}{ Polyunsaturated fatty acid } \\
\hline $\mathrm{C} 18: 2 \omega 6$ & $5.37 \pm 0.14^{\mathrm{ab}}$ & $5.22 \pm 0.36^{b}$ & $5.26 \pm 0.10^{b}$ & $5.89 \pm 0.22^{\mathrm{a}}$ & 0.10 \\
\hline $\mathrm{C} 18: 3 \omega 3$ & $2.19 \pm 0.18^{b}$ & $2.81 \pm 0.23^{\mathrm{a}}$ & $1.69 \pm 0.00^{c}$ & $0.85 \pm 0.09^{d}$ & $<0.01$ \\
\hline $\mathrm{C} 18: 4 \omega 3$ & $4.76 \pm 0.38^{b}$ & $6.63 \pm 2.37^{\mathrm{abc}}$ & $3.46 \pm 0.21^{c}$ & $6.96 \pm 0.67^{\mathrm{a}}$ & 0.05 \\
\hline $\mathrm{C} 20: 3 \omega 6$ & $0.40 \pm 0.28$ & $0.54 \pm 0.29$ & $0.77 \pm 0.02$ & $0.24 \pm 0.02$ & 0.07 \\
\hline $\mathrm{C} 20: 4 \omega 6$ & $0.76 \pm 0.02^{b}$ & $1.81 \pm 0.96^{\mathrm{ab}}$ & $1.93 \pm 0.04^{\mathrm{a}}$ & $0.77 \pm 0.08^{b}$ & 0.02 \\
\hline $\mathrm{C} 20: 5 \omega 3$ & $10.0 \pm 0.93$ & $9.70 \pm 0.81$ & $10.6 \pm 0.31$ & $9.59 \pm 0.57$ & 0.50 \\
\hline $\mathrm{C} 22: 5 \omega 3$ & $2.06 \pm 0.31$ & $2.09 \pm 0.21$ & $1.96 \pm 0.09$ & $1.89 \pm 0.25$ & 0.65 \\
\hline $\mathrm{C} 22: 6 \omega 3$ & $9.01 \pm 1.07$ & $10.4 \pm 2.32$ & $9.28 \pm 0.02$ & $8.79 \pm 1.52$ & 0.79 \\
\hline Other & $3.01 \pm 0.17^{b}$ & $3.86 \pm 0.05^{\mathrm{a}}$ & $3.90 \pm 0.14^{\mathrm{a}}$ & $2.89 \pm 0.52^{\mathrm{ab}}$ & 0.02 \\
\hline Total & $37.6 \pm 2.26^{b}$ & $43.5 \pm 2.61^{a}$ & $39.5 \pm 0.77^{a b}$ & $37.9 \pm 1.33^{b}$ & $<0.01$ \\
\hline Total $\omega 3$ & $28.6 \pm 2.24$ & $32.8 \pm 3.97$ & $28.6 \pm 0.77$ & $28.6 \pm 1.77$ & 0.27 \\
\hline Total $\omega 6$ & $6.53 \pm 0.37$ & $7.57 \pm 1.49$ & $7.96 \pm 0.16$ & $6.90 \pm 0.26$ & 0.30 \\
\hline$\omega 3 / \omega 6$ & $4.39 \pm 0.52$ & $4.54 \pm 1.38$ & $3.59 \pm 0.02$ & $4.14 \pm 0.25$ & 0.51 \\
\hline DHA/EPA & $0.90 \pm 0.05$ & $1.08 \pm 0.30$ & $0.88 \pm 0.02$ & $0.91 \pm 0.12$ & 0.90 \\
\hline EPA/ARA & $13.2 \pm 1.33^{a}$ & $6.67 \pm 3.36^{a b}$ & $5.46 \pm 0.05^{b}$ & $12.5 \pm 0.92^{a}$ & 0.02 \\
\hline
\end{tabular}

Data are expressed as mean $\pm \mathrm{SD}$; Different letters within the same row represent statistical differences $(\mathrm{P}<0.05)$. 
Table 9

Skin color parameters of commercial size red porgy (P. pagrus) fed with different experimental diets.

\begin{tabular}{llll}
\hline & \multicolumn{2}{l}{ Pectoral Region } & \multicolumn{2}{c}{ Caudal Region } \\
\cline { 2 - 4 } & $\mathrm{a}^{*}$ & $\mathrm{~b}^{*}$ & $\mathrm{a}^{*}$ \\
$\mathrm{Ctrl}$ & $4.01 \pm 0.92^{\mathrm{c}}$ & $11.19 \pm 1.59$ & $5.19 \pm 1.76^{\mathrm{b}}$ \\
$\mathrm{A}_{50}$ & $5.92 \pm 2.02^{\mathrm{b}}$ & $10.93 \pm 2.16$ & $9.06 \pm 1.92^{\mathrm{a}}$ \\
$\mathrm{A}_{80}$ & $8.23 \pm 2.09^{\mathrm{a}}$ & $11.80 \pm 2.28$ & $10.84 \pm 2.82^{\mathrm{a}}$ \\
$\mathrm{A}_{50} \mathrm{~A}_{80}$ & $8.58 \pm 2.12^{\mathrm{a}}$ & $12.11 \pm 2.21$ & $13.44 \pm 2.29$ \\
$P$-value & $<0.01$ & 0.42 & $13.03 \pm 2.57$ \\
\hline
\end{tabular}

$a^{*}$ : redness/greenness chromaticity; $b^{*}:$ yellowness/bluish chromaticity. Data are expressed as mean $\pm S D(n=25 /$ treatment); Different letters within the same column represent statistical differences $(\mathrm{P}<0.05)$.
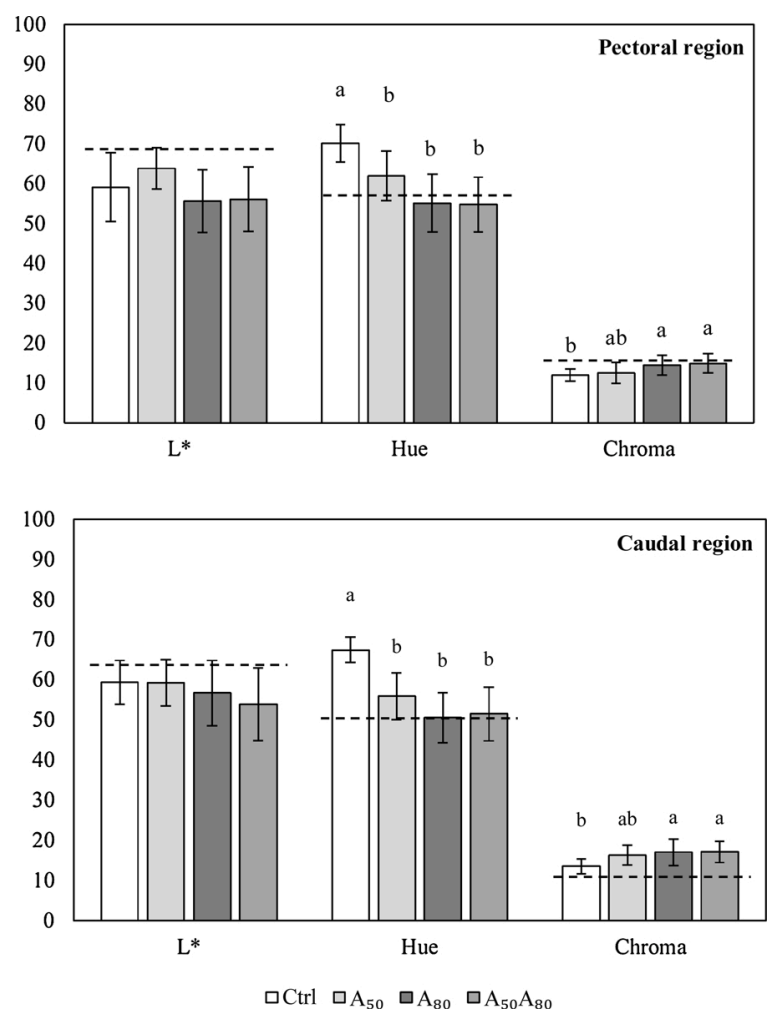

Fig. 2. Skin color in the pectoral and caudal regions of the commercial size red porgy ( $P$. pagrus) fed different experimental diets. Data are expressed as mean \pm SD. Different letters represent statistical differences $(P<0.05)$. Dotted lines represent mean values reported for wild red porgy in Kalinowski et al. (2007).

\section{Discussion}

\subsection{Fish performance}

Carotenoids are responsible for fish skin and flesh pigmentation, but increasing attention is being directed towards other biological functions of these compounds in aquatic animals, such as promoting growth and reproduction, antioxidant and as immunostimulant activities. Dietary supplementation with astaxanthin at the tested concentrations did not affect growth performance, hepatosomatic index and feed utilization of commercial sized red porgy, which agrees with earlier observations for the same species fed different sources and concentrations of dietary astaxanthin (Cejas et al., 2003; Chatzifotis et al., 2005; Kalinowski et al., 2005; Tejera et al., 2007; Manganaro et al., 2012). The present results are also in line with studies carried out with Australian snapper, Pagrus auratus (Doolan et al., 2009), olive flounder, Paralichthys olivaceus (Pham et al., 2014), gilthead seabream Sparus aurata (Gomes et al., 2002; Wassef et al., 2010), Atlantic Salmon, Salmo salar (Baker et al., 2002) and rainbow trout, Oncorhyncus mykiss (Rahman et al., 2016; Noori and Razi, 2017). Conversely, an increasing number of research work revealed significant positive influence between dietary astaxanthin supplementation and somatic growth of several fish species, like rainbow trout (Oncorhynchus mykiss; Bazyar et al., 2010), Atlantic cod (Gadus morhua; Hansen et al., 2016), large Yellow Croaker (Pseudosciaena crocea; Li et al., 2014). Kalinowski et al. (2011) 


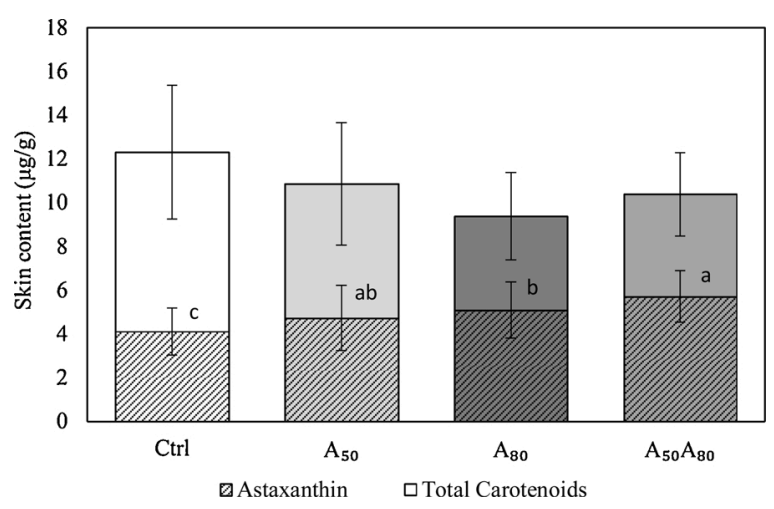

Fig. 3. Total carotenoids and astaxanthin content $(\mu \mathrm{g} / \mathrm{g})$ in the skin of commercial sized red porgy (P. pagrus) fed different experimental diets. Data are expressed as mean $\pm \mathrm{SD}$. Different letters represent statistical differences $(\mathrm{P}<0.05)$.

reported increased final body weight, weight gain and eviscerated weight after feeding red porgy juveniles (226.9 g) for 90 days with a diet supplemented with $100 \mathrm{mg} / \mathrm{kg}$ of Carophyll ${ }^{\circledR}$ Pink. In the current study, fish initial weight averaged $386 \mathrm{~g}$, which is within the range size (325-425 g) that P. pagrus, a protogynous hermaphrodite species, has sexual reversal (Manooch, 1975) thus requiring different priorities of energy allocation. In fact, data inferred from red porgy growth trials in intensive culture conditions shows that exponential growth phase from hatching (day 0 ) onwards (weight $(\mathrm{g})=11.601 \mathrm{e}^{0.677 \text { (days) }} ; \mathrm{r}^{2}=0.912 ; \mathrm{n}=66,873$ ) is followed by an inflexion point at $370 \mathrm{~g}$ of slower growth (Kentouri et al., 1995), which could explain the lower SGRs achieved in the present study, when compared to those reported by Kalinowski et al. (2011). That may also contribute to the fact that there was no noticeable effect of dietary astaxanthin supplementation on somatic growth in the present study, though there was no sign of sexual maturation yet. These various results highlight the fact that the mechanisms by which carotenoids may influence fish growth are not well elucidated (Kalinowski et al., 2015). Being considered as micronutrients in fish nutrition, carotenoids are expected to affect other physiological responses not necessarily reflecting into somatic growth (Noori and Razi, 2017).

\subsection{Lipid metabolism}

Depending on the species, nutritional state, the life-stage or the physiological state, fish tend to accumulate lipids in different anatomical sites (muscle, liver, mesenteric fat), (Flynn et al., 2009; Weil et al., 2013; He et al., 2015). Also, cultured fish fed commercial diets generally exhibit a greater body fat content than wild specimens (Ackman, 1989), reflecting lipid composition of the diets. Regardless the astaxanthin supplementation, the present results on white muscle composition allow considering red porgy as a "lean fish" (below $2 \%$ lipid content in wet weight) according to the classification of Ackman (1989), which agrees to what was previously observed by Rueda et al. (1997) and García-Romero et al. (2014).

Not surprisingly, preferential lipid storage occurred in mesenteric fat, followed by the liver. Astaxanthin supplementation did not affect the lipid content of mesenteric fat or the liver, for what it can be considered that the astaxanthin dietary supplementation levels used in this experiment were not high enough to produce significant metabolic changes in red porgy. Furthermore, the results on fatty acid composition, particularly, SFA, MUFA and PUFA of the individual lipid classes (phospholipids, glycolipids and neutral lipids) of the liver of red porgy were similar across all dietary treatments. It could be expected that astaxanthin supplementation would enhance lipid utilization in tissues such as the liver and mesenteric fat that are rich in readily oxidized PUFA (Halliwel and Chirico 1993). Kalinowski et al. (2011) found that feeding red porgy juveniles with astaxanthin supplemented diets for 120 days (100 mg of Carophyll ${ }^{\circledR}$ Pink per kg diet) decreased total lipids and palmitic acid (SFA; C16:0) content in the liver, while increasing EPA (PUFA;

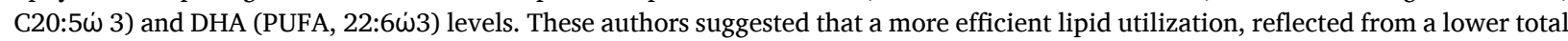
lipid content in the whole body and liver, would have translated into improved growth performance. Conversely, Tejera et al. (2007, 2010) did not find any effects of shrimp meal or Carophyll Pink supplementation on the lipid composition of the skin of red porgy fry. Likewise, Pham et al. (2014) did not find clear differences in the liver fatty acids composition of olive flounder juveniles fed diets

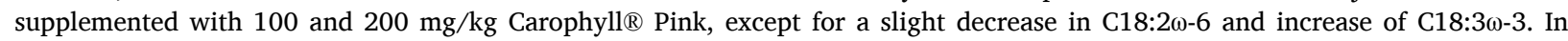
agreement with the previous authors (Tejera et al., 2007, 2010; Pham et al., 2014), in the present study there was no effect on the unsaturated fatty acids content in any of the three lipid classes. Further studies on the astaxanthin supplementation on primary lipid peroxidation, measured by thiobarbituric acid reactive substances of the liver should be performed. Alternately, antioxidant properties of astaxanthin could be evaluated by the activity of antioxidant enzymes. Antioxidant activity involves a wide range of enzymes, including superoxide dismutase; plasma catalase that are known to be inversely related to the dietary carotenoid content (Rahman et al., 2016), as previously shown in juvenile olive flounder by Pham et al. (2014). Also, mesenteric fat, which is the main lipid depot and well suited for long-term lipid storage (Rueda et al., 1997), was composed by more than 85 \% of lipids, without significant differences across different diets $(\mathrm{P}>0.05)$. Neutral lipids were overrepresented in this tissue, whereas relative higher amounts of phospholipids and glycolipids were found in the liver. Analysis of the fatty acid patterns of the lipid fractionation showed that the mesenteric fat fatty acids composition followed the general liver composition and percentages of several fatty acids differed between 
fractions, regardless of the dietary treatment. As reported for other fish, in all analyzed tissues, $\omega 3$-fatty acids levels made up a larger fraction than $\omega 6$-fatty acids (Greene and Selivonchick, 1987; Ackman, 1992; Tornaritis et al., 1994). According to Ackman (1967), MUFA and SFA constitute the main groups of fatty acids in neutral lipids of most fish and phospholipids usually contain very high levels of PUFA, particularly of DHA (Brockerhoff et al., 1963; Delgado et al., 1994). However, the present results showed that liver phospholipid fraction had the lowest PUFA (3-18\%) and DHA (0.6-3\%) content, mostly due to higher content in SFA (42-54 \%). Similar to Rueda (1997) findings in wild red porgy, in the present study liver PUFA contents were higher in both neutral (triglycerides fraction-28-32\%) and glycolipids fraction (29-40\%) than in the phospholipids fraction, the glycolipids showing the highest DHA levels (12-21\%). Nonetheless, comparison of fatty acids composition of different lipid fractions between liver and mesenteric fat, revealed consistently higher PUFA (34-44\%) contents in all three fractions of mesenteric fat, while PUFA content of the liver varied between $3-18 \%$ in phospholipids, between $29-41 \%$ in glycolipids and $28-32 \%$ in the neutral fraction. In the present study, PUFA and DHA contents in liver and mesenteric fat were higher those reported by Kalinowski et al. (2011, 2015), who found 18-21 \% PUFA and 7.71-9.34 \% DHA in the liver and 19.5-21.4 \% PUFA and 8.1-9.3 \% DHA in mesenteric fat of red porgy.

\subsection{Skin color and carotenoid accumulation}

Carotenoid pigments, primarily astaxanthin diester and tunaxanthin, are responsible for the bright reds and yellows seen in several species of seawater red skinned fish (Matsuno et al., 1985; Miki et al., 1985), including red porgy (Tejera et al., 2007). Achieving natural pigmentation is of outmost importance to commercial operations, since it affects consumers perception of product quality (e.g. health, freshness, nutritive value and taste) and ultimately, product price (Carvalho and Caramujo, 2017; Lim et al., 2018). The measurement of color variables such as redness ( $\left.a^{*}\right)$, yellowness $\left(b^{*}\right)$, hue and chroma give information on the deposition of the referred skin carotenoids (Kalinowski et al., 2007) specially in the front lateral zone, as this area seems to accumulate more astaxanthin with less variability (Kalinowski et al., 2005). In the current study, there was a high variation in the carotenoid content between groups and no tendency was observed with dietary astaxanthin supplementation. However, according to what was expected, astaxanthin content tended to increase in fish fed the astaxanthin supplemented diets, which was also reflected in redness values. Like what was reported by Chatzifotis et al. (2005) and Kalinowski et al. (2011), the dietary supplementation with astaxanthin (at 50 , 80 or 50 followed by $80 \mathrm{mg} / \mathrm{kg}$ ) also influenced positively skin hue and chroma of red porgy. Hue values of both pectoral and caudal regions were similar amongst the groups fed the astaxanthin supplemented diets, but lower than those of the control group and closer to those referenced for wild individuals (Kalinowski et al., 2007; García-Romero et al., 2010). Chroma also increased in fish fed astaxanthin supplemented diets, the present values being closer to those reported for wild fish, though slightly lower in the pectoral region. Lower chroma values were mostly linked with lower b* values (yellowness), reflecting possible low yellow carotenoids content (tunaxanthin). Although synthesis of this yellow xanthophyll from dietary astaxanthin has been reported for red porgy by Tejera et al. (2007) and for Japanese red sea bream (Allahpichay et al., 1984), Kalinowski et al. (2007) suggested that red porgy may have a limited synthesis capacity, similarly to what has been suggested by Yi et al. (2014) for the yellow croaker, Larimichthys croceus.

Red porgy skin lightness $\left(\mathrm{L}^{*}\right)$ was not affected by astaxanthin supplementation in the diets, though cultured red porgy presented lower $L^{*}$ values, when compared to wild red porgies (Kalinowski et al., 2007; García-Romero et al., 2010). Likewise, several other authors (Chatzifotis et al., 2005; Kalinowski et al., 2005; García-Romero et al., 2010, 2014) concluded that this color parameter was not influenced by different pigment supplementation concentrations and feeding trial duration in red porgy. It has been suggested that several factors may influence skin lightness, including overproduction of melanin as a response to culture conditions, such as background color or light intensity (Booth et al., 2004; Van der Salm et al., 2004, 2006; Pavlidis et al., 2008; Tejera et al., 2010; Papandroulakis et al., 2013). This effect has also been reported in red sea bream (Lin et al., 1998) and Australian snapper (Booth et al., 2004).

\section{Conclusions}

Red porgy has great potential for large-scale commercial production. Aquaculture operators recognize the opportunity for red porgy production in several international markets once discoloration problems are bypassed. In the present study the dietary astaxanthin supplementation (at 50 or $80 \mathrm{mg} / \mathrm{kg}$ for 6 months or at $50 \mathrm{mg} / \mathrm{kg}$ for 3 months followed by $80 \mathrm{mg} / \mathrm{kg}$ for $3 \mathrm{months}$ ) improved the skin color in large size commercial red porgy, as it increased redness/greenness chromaticity and the achieved hue and chroma values were close to those previously reported for wild individuals. The present study results are encouraging but call for further research on carotenoid supplementation in finishing diets for red porgy. As the commercial grow out of red porgy may demand the use of offshore cages or net pens, future works should consider performing the trials in offshore cages, as this may influence final coloration of red porgy (the lightness in particular). Finally, studies on the combination of astaxanthin with tunaxanthin should be considered, as both xanthophylls seem to contribute for an adequate skin pigmentation of this sparid species.

\section{Author statement}

Natacha Nogueira: Conceptualization, Methodology, Laboratory analyses, Writing, Supervision, Reviewing and Editing. Paula Canada: Writing, Data curation.

Jose Caboz: Laboratory analysis, Data curation.

Carlos Andrade: Resources, Reviewing.

Nereida Cordeiro: Conceptualization, Methodology, Supervision, Funding acquisition, Resources, Reviewing and Editing. 


\section{Declaration of Competing Interest}

The authors declare no conflict of interest.

\section{Acknowledgements}

This research did not receive any specific grant from funding agencies in the public, commercial, or not-for-profit sectors. Paula Canada was financially supported by the Oceanic Observatory of Madeira Project (M1420-01-0145-FEDER-000001) through the grant ARDITI-OOM-2016-007.

\section{Appendix A. Supplementary data}

Supplementary material related to this article can be found, in the online version, at doi:https://doi.org/10.1016/j.anifeedsci. 2021.114916.

\section{References}

Ackman, R.G., 1967. Characteristics of the fatty acid composition and biochemistry of some fresh-water fish oils and lipids in comparison with marine oils and lipids. Comp. Biochem. Physiol. 22, 907-922. https://doi.org/10.1016/0010-406X(67)90781-5.

Ackman, R.G., 1989. Nutritional composition of fats in seafood. Prog. Food Nutr. Sci. 13, 161-241.

Ackman, R.G., 1992. Fatty acids in fish and shellfish. In: Kuang, C.Ch. (Ed.), Fatty Acids in Foods and Their Health Implications. Marcel Dekker, Inc., New York, pp. 169-184.

Allahpichay, I., Chiaki, S., Michiko, K., 1984. Pigmentation of cultured red sea bream, Chrysophrys major, using astaxanthin from Antarctic krill, Euphausia superba, and a mysid, Neomysis sp. Aquaculture 38 (1), 45-57. https://doi.org/10.1016/0044-8486(84)90136-4.

Almansa, E., Martín, M.V., Cejas, J.R., Badía, P., Jeréz, S., Lorenzo, A., 2001. Lipid and fatty acid composition of female gilthead seabream during their reproductive cycle: effects of a diet lacking n-3 HU-FA. J. Fish Biol. 59, 267-286. https://doi.org/10.1111/j.1095-8649.2001.tb00129.x.

Amar, E.C., Kiron, V., Satoh, S., Watanabe, T., 2001. Influence of various dietary synthetic carotenoisa on bio-defence mechanism in rainbow trout, Oncorhynchus mykiss Walbaum. Aquac. Res. 32, 162-173. https://doi.org/10.1046/j.1355-557x.2001.00051.x.

Amar, E.C., Kiron, V., Akutsu, T., Satoh, S., Watanabe, T., 2012. Resistance of rainbow trout Oncorhynchus mykiss to infectious hematopoietic necrosis virus (IHNV) experimental infection following ingestion of natural and synthetic carotenoids. Aquaculture 330-333, 148-155. http://hdl.handle.net/10862/1593.

Andrade, C.A.P., Brazão, I.P.G., Nogueira, N., Ferreira, M.P., Dillinger, T., Dinis, M.T., Narciso, L., 2011. Red porgy (Pagrus pagrus) larval feeding performance and behavior at the onset of exogenous feeding. J. Exp. Mar. Biol. Ecol. 407, 377-381. https://doi.org/10.1016/j.jembe.2011.07.034.

Andrade, C.A.P., Nogueira, N., Silva, P., Dinis, M.T., Narciso, L., 2012. Mesocosm hatcheries using semi-intensive methodologies and species diversification in aquaculture. J. Agr. Sci. Tech. B 2, 428-437.

Andrade, C.A.P., Nascimento, F.J.A., Nogueira, N., Pimenta, F., Dinis, M.T., Narciso, L., 2013. Allometric growth in red porgy Pagrus pagrus larvae: developing morphological indices for mesocosm semi-intensive culture. N. Am. J. Aquac. 75, 42-49. https://doi.org/10.1080/15222055.2012.713894.

AOAC - Association of Oficial Agricultural Chemist, 1975. Oficial Method of Analysis, $12^{\text {nd }}$ ed. AOAC, Washington, DC.

Aristzabal, E., Suárez, J., Vega, A., Bargas, R., 2009. Egg and quality assessment in the Argentinean red porgy (Pagrus pagrus). Aquaculture 287 (3-4), 329-334. https://doi.org/10.1016/j.aquaculture.2008.10.044.

Baker, R.T.M., Pfeiffer, A.M., Schöner, F.J., Smith-Lemmon, L., 2002. Pigmenting efficacy of astaxanthin and canthaxanthin in fresh water reared Atlantic salmon, Salmo salar. Anim. Feed Sci. Technol. 99, 97-106. https://doi.org/10.1016/s0377-8401(02)00116-5.

Basurco, B., Lovatelli, A., Garcia, B., 2011. Current status of sparidae aquaculture. In: Pavlidis, Michail A., Mylonas, Constantinos C. (Eds.), Sparidae. Biology and Aquaculture of Gilthead Sea Bream and Other Species. Blackwell Publishing Ltd, pp. 1-50.

Bazyar, L.A.A., Ahamadi, M.R., Safi, S., Ytrestoyl, T., Bjerkeng, B., 2010. Growth performance, mortality and carotenoid pigmentation of fry offspring as affected by dietary supplementation of astaxanthin to female rainbow trout (Oncorhynchus mykiss) broodstock. J. Appl. Icthyol. 26, 35-39. https://doi.org/10.1111/j.14390426.2009.01349.x.

Bell, J.G., Sargent, J.R., 2003. Araquidonic acid in aquaculture feeds: current status and future opportunities. Aquaculture 218, 491-499. https://doi.org/10.1016/ s0044-8486(02)00370-8.

Bligh, E.G., Dyer, W.J., 1959. A rapid method of total lipid extraction and purification. Can. J. Biochem. Physiol. 37, 911-917.

Boccard, R., Buchter, L., Casteels, E., Cosentino, E., Dransfield, E., Hood, D.E., Joseph, R.L., MacDougall, D.B., Rhodes, D.N., Schön, I., Timbergen, B.J., Touraille, C., 1981. Procedures for measuring meat quality characteristics in beef production experiments. Report of a working group in the Commission of the European Communities' (CEC) beef production research programme. Livest Prod Sci. 8, 385-397. https://doi.org/10.1016/0301-6226(81)90061-0.

Booth, M.A., Warner-Smith, R.J., Allan, G.L., Glencross, B.D., 2004. Effects of dietary astaxanthin source and light manipulation on the skin colour of Australian snapper Pagrus auratus (Bloch \& Schneider, 1801). Aquac. Res. 35, 458-464. https://doi.org/10.1111/j.1365-2109.2004.01038.x.

Brockerhoff, H., Ackman, R.G., Hoyle, R.J., 1963. Specific distribution of fatty acid in marine lipids. Arch. Biochem. Biophys. 100, 9-12. https://doi.org/10.1016/ 0003-9861(63)90026-2.

Carvalho, C.C.C.R., Caramujo, M.J., 2017. Carotenoids in aquatic ecosystems and aquaculture: a colorful business with implications for human health. Front. Mar. Sci. 4, 93. https://doi.org/10.3389/fmars.2017.00093.

Cejas, J.R., Almansa, E., Tejera, N., Jerez, S., Bolannos, A., Lorenzo, A., 2003. Effect of dietary supplementation with shrimp on skin pigmentation and lipid composition of red porgy (Pagrus pagrus) alevins. Aquaculture 218, 457-469. https://doi.org/10.1016/S0044-8486(02)00226-0.

Chatzifotis, S., Pavlidis, M., Doñate Jimeno, C., Vardanis, G., Sterioti, A., Divanach, P., 2005. The effect of different carotenoid sources on skin coloration of cultured red porgy (Pagrus pagrus). Aquac. Res. 36, 1517-1525. https://doi.org/10.1111/j.1365-2109.2005.01374.x.

Chatzifotis, S., Vaz Juan, I., Kyriazi, P., Divanach, P., Pavlidis, M., 2011. Dietary carotenoids and skin melanin content influence the coloration of farmed red Porgy (Pagrus pagrus). Aquacult. Nutr. 17 (2), 90-100. https://doi.org/10.1111/j.1365-2095.2009.00738.x.

Christiansen, R., Torrissen, J., 1996. Growth and survival of Atlantic salmon, Salmo salar fed different dietary levels of astaxanthin. Aquacult. Nutr. 2 (1), 55-62. https://doi.org/10.1111/j.1365-2095.1996.tb00008.x.

CIE Colorimetry, 1976. Commission internationale de l'éclairage. Publication 15. Bureau Central de la CIE, Wien.

Cifuentes, A.S., González, M.A., Vargas, S., Hoeneisen, M., González, N., 2003. Optimization of biomass, total carotenoids and astaxanthin production in Haematococcus pluvialis flotow Strain Steptoe (Nevada, USA) under laboratory conditions. Biol. Res. 36 (3-4), 343-357. https://doi.org/10.4067/s071697602003000300006 . 
Cohen, Z., Vonshak, A., Richmond, A., 1988. Effect of environmental conditions on fatty acid composition of the red alga porphyridium correlation to growth rate. J. Phycol. 24, 328-332. https://doi.org/10.1111/j.1529-8817.1988.tb04474.x.

da Costa, D.P., Miranda-Filho, K.C., 2020. The use of carotenoid pigments as food aditives for aquatic organisms and their functional roles. Rev. Aquac. 12-3, 1567-1578. https://doi.org/10.1111/raq.12398.

Davies, B.H., 1976. In: Goodwin, T.W. (Ed.), Chemistry and Biochemistry of Plant Pigments, 2nd ed., Vol. 2. Academic Press, New York, pp. 38-165.

Delgado, A., Estevez, A., Hortelano, P., Alejandre, M.J., 1994. Analyses of fatty acids from different lipids in liver and muscle of sea bass (Dicentrarchus labrax L.). Influence of temperature and fasting. Comp. Biochem. Physiol. 108A, 673-680. https://doi.org/10.1016/0300-9629(94)90354-9.

Dhankhar, J., Kadian, S.S., Sharma, A., 2012. Astaxanthin: a potential carotenoid. Int. J. Pharm. Sci. Res. 3 (5), 1246-1259. https://doi.org/10.13040/IJPSR.09758232.3(5).1246-59.

Doolan, B.J., Booth, M.A., Allan, G.L., Jones, P.L., 2009. Effects of dietary astaxanthin concentration and feeding period on the skin pigmentation of Australian snapper Pagrus auratus (Bloch \& Schneider, 1801). Aquac. Res. 40, 60-68. https://doi.org/10.1111/j.1365-2109.2008.02063.x.

Flynn, E.J., Trent, C.M., Rawls, J.F., 2009. Ontogeny and nutritional control of adipogenesis in zebrafish (Danio rerio). J. Lipid Res. 50, 1641-1652. https://doi.org/ 10.1194/jlr.M800590-JLR200.

García-Romero, J., Kalinowski, C.T.H., Izquierdo, M.S.L., Robaina, L., 2010. Marine and freshwater crab meals in diets for red porgy (Pagrus pagrus): effect on growth, fish composition and skin color. Aquac. Res. 41, 1759-1769. https://doi.org/10.1111/j.1365-2109.2009.02476.x.

García-Romero, J., Ginés, R., Izquierdo, M.S.L., Robaina, L., 2014. Effect of dietary substitution of fish meal for marine crab and echinoderm meals on growth performance, ammonia excretion, skin colour, and flesh quality and oxidation of red porgy (Pagrus pagrus). Aquaculture 422-423, 239-248. https://doi.org/ 10.1016/j.aquaculture.2013.11.024.

Gomes, E., Dias, J., Silva, P., Valente, L., Empis, J., Gouveia, L., Bowen, J., Young, A., 2002. Utilization of natural and synthetic sources of carotenoids in the skin pigmentation of gilthead seabream (Sparus aurata). Eur. Food Res. Technol. 214, 287-293. https://doi.org/10.1007/s00217-001-0475-9.

Goodwin, T.W., 1984. The Biochemistry of the Carotenoids. Animals, vol. 2. Chapman \& Hall, New York.

Greene, D.H.S., Selivonchick, D.P., 1987. Lipid metabolism in fish. Prog. Lipid Res. 26, 53-85. https://doi.org/10.1016/0163-7827(87)90008-7.

Guckert, J.B., Antworth, C.P., Nichols, P.D., White, D.C., 1985. Phospholipid, ester-linked fatty acid profiles as reproducible assays for changes in prokaryotic community structure of estuarine sediments. Microb. Ecol. 31, 147-158. https://doi.org/10.1111/j.1574-6968.1985.tb01143.x.

Guillaume, J., Choubert, G., 2001. Digestive physiology and nutrient digestibility in fishes. In: Guillaume, J., Kaushik, S., Bergot, P., Métailler, R. (Eds.), Nutrition and Feeding of Fish and Crustaceans. Springer-Praxis, Chichester, pp. 183-196.

Ha, B.S., Kang, D.S., Kim, J.H., Choi, O.S., Ryu, H.Y., 1993. Metabolism of dietary carotenoids and effects to improve the body color of cultured founder and red sea bream. Bull. Korean Fish. Soc. 26, 91-101.

Hansen, O.J., Puvanendran, V., Bangera, R., 2016. Broodstock diet with water and astaxanthin improve condition and egg output of broodstock fish and larval survival in Atlantic cod, Gadus morhua L. Aquac. Res. 47, 819-829. https://doi.org/10.1111/are.12540.

He, A.-Y., Ning, L.-J., Chen, L.-Q., Chen, Y.-L., Xing, Q., Li, J.-M., Qiao, F., Li, D.-L., Zhang, M.-L., Du, Z.-Y., 2015. Systemic adaptation of lipid metabolism in response to low- and high-fat diet in Nile tilapia (Oreochromis niloticus). Physiol. Rep. 3, e12485 https://doi.org/10.14814/phy2.12485.

Hu, X., Li, Y., Li, Ch., Fu, Y., Cai, F., Chen, Q., Li, D., 2012. Combination of fucoxanthin and conjugated linoleic acid attenuates body weight gain and improves lipid metabolism in high-fat diet-induced obese rats. Arch. Biochem. Biophys. 519, 59-65. https://doi.org/10.1016/j.abb.2012.01.011.

Kalinowski, T., Robaina, L., Fernandez-Palacios, H., Schuchardt, D., Izquierdo, M.S., 2005. Effect of different carotenoid sources and their dietary levels on red porgy (Pagrus pagrus) growth and skin colour. Aquaculture 244, 223-231. https://doi.org/10.1016/j.aquaculture.2004.11.001.

Kalinowski, C.T., Izquierdo, M.S., Schuchardt, D., Robaina, L.E., 2007. Dietary supplementation time with shrimp shell meal on red porgy (Pagrus pagrus) skin colour and carotenoid concentration. Aquaculture 272, 451-457. https://doi.org/10.1016/j.aquaculture.2007.06.008.

Kalinowski, C.T., Robaina, L., Izquierdo, M.S., 2011. Effect of dietary astaxanthin on the growth performance, lipid composition and post-mortem skin colouration of red porgy (Pagrus pagrus). Aquac. Int. 19, 811-823. https://doi.org/10.1007/s10499-010-9401-0.

Kalinowski, C.T., Socorro, J., Robaina, L.E., 2015. Effect of dietary canthaxanthin on the growth and lipid composition of red porgy (Pagrus pagrus). Aquac. Res. 46, 893-900 https://doi.org/10.111/are.12245.

Kentouri, M., Pavlides, M., Papandroulakis, N., Divanach, P., 1995. Culture of the red porgy, Pagrus pagrus in Crete. Present knowledge, problems and perspectives. In: Valls, M., Akrout, H. (Eds.), Cahier Options Mediterranennes, Vol. 16. Mediterranean Marine Aquaculture Finfish Species Diversification, C.I.H.E.A.M., Zaragoza, Spain, pp. 65-78.

Koshio, S., 2002. Red sea bream. In: Webster, C.D., Lim, C.E. (Eds.), Nutrient Requirements and Feeding of Finfish for Aquaculture. CABI, Wallingford, pp. 53-63.

Lepage, G., Roy, C.C., 1986. Direct transesterification of all classes of lipids in a one-step reaction. J. Lipid Res. 27, 114-120.

Li, M., Wu, W., Zhou, P., Xie, F., Zhou, Q., Mai, K., 2014. Comparison effect of dietary astaxanthin and Haematococcus pluvialis on growth performance, antioxidant status and immune response of large yellow croaker Pseudosciaena crocea. Aquaculture 434, 227-232. https://doi.org/10.1016/j.aquaculture.2014.08.022.

Liebler, D.C., 1993. Antioxidant reactions of carotenoids. Ann. N. Y. Acad. Sci. 691, 20-31. https://doi.org/10.1111/j.1749-6632.1993.tb26154.x.

Lim, K.C., Yusoff, F.Md., Shariff, M., Kamarudin, M.S., 2018. Astaxanthin as feed supplement in aquatic animals. Rev. Aquac. 10, 738-773. https://doi.org/10.1111/ raq. 12200.

Lin, M.Q., Ushio, H., Ohshima, T., Yamanaka, H., Koizumi, C., 1998. Skin color control of the red sea bream (Pagrus major). LWT-Food Sci. Technol. 31 (1), 27-32. https://doi.org/10.1006/fstl.1997.0280.

Manganaro, A., Sanfilippo, M., Fortino, G., Dapra, F., Palmegiano, G.B., Gai, F., 2012. Artificial pigmentation and flesh quality in red porgy (Pagrus pagrus). Int. Aquac. Res. 4, 1-12. https://doi.org/10.11233/aquaculturesci1953.55.441.

Manooch, C.S., 1975. A Study of the Taxonomy, Exploitation, Life History, Ecology and Tagging of the Red Porgy, Pagrus pagrus Linnaeus, of the Carolinas. Ph.D. Thesis. North Carolina State Univ., Raleigh, NC.

Mary, N., Achuthan, C., Babu, B., Padikkala, J., 2003. In vitro antioxidant and antithrombotic activity of Hemidesmus indicus (L) R. Br. J. Ethnopharmacol. 87, 187-191. https://doi.org/10.1016/s0378-8741(03)00119-3.

Matsuno, T., Ookubo, M., Komori, T., 1985. Carotenoids of tunicates. III: the structural elucidation of two new marine carotenoids, amarouciaxanthin A and B. J. Nat. Prod. 48, 606-613. https://doi.org/10.1021/np50040a015.

Miki, W., Yamaguchi, K., Konosu, S., Takane, T., Satake, M., Fujita, T., Kuwabara, H., Shimeno, S., Takeda, M., 1985. Origin of tunaxanthin in the integument of yellowtail (Seriola quinqueradiata). Biochem. Mol. Biol. 80, 195-201. https://doi.org/10.1016/0305-0491(85)90195-6.

Morris Jr, J.A., Resek, T.C., McNeill, N.A., Watanabe, W.O., 2008. Aquaculture of Atlantic Red Porgy. N. Am. J. Aquac. 70 (2), 184-191. https://doi.org/10.1577/ A06-073.1.

Nakano, T., Tosa, M., Takeuchi, M., 1995. Improvement of biochemical features in fish health by red yeast and synthetic astaxanthin. J. Agric. Food Chem. 43, 1570-1573. https://doi.org/10.1021/jf00054a029.

Nickell, D.C., Bromage, N.R., 1998. The effect of timing and duration of feeding astaxanthin on the development and variation of fillet colour and efficiency of pigmentation in rainbow trout (Oncorhynchus mykiss). Aquaculture 169, 233-246. https://doi.org/10.1016/S0044-8486(98)00385-8.

Noori, A., Razi, A., 2017. Effects of dietary astaxanthin on the growth and skin and muscle pigmentation of sexually immature rainbow trout Oncorhynchus mykiss (Walbaum, 1792) (Teleostei: salmonidae). Iran. J. Ichthyol. 4 (4), 361-374. https://doi.org/10.22034/iji.v4i4.234015.

Papandroulakis, N., Mesa Rodriguez, A., Anastasiadis, P., Lisak, D., Asderis, M., Pavlidis, M., 2013. Installation, operation and evalution of a submerged cage at 45M depth in Crete for the rearing of red porgy Pagrus Pagrus. Aquac. Res. 44 (8), 1196-1205. https://doi.org/10.1111/j.1365-2109.2012.03119.x.

Pavlidis, M., Karkana, M., Fanouraki, E., Papadroulakis, N., 2008. Environmental control of skin color in the red porgy, Pagrus pagrus. Aquac. Res. 39 , 837-849. https://doi.org/10.1111/j.1365-2109.2008.01937.x.

Pavlidis, M., Mylonas, C. (Eds.), 2011. Sparidae: Biology and Aquaculture of Gilthead Seabram and Other Species. John Wiley \& Sons.

Pham, M.A., Byun, H.-G., Kim, K.-D., Lee, S.-M., 2014. Effects of dietary carotenoid source and level on growth, skin pigmentation, antioxidant activity and chemical composition of juvenile olive flounder Paralichthys olivaceus. Aquaculture 431, 65-72. https://doi.org/10.1016/j.aquaculture.2014.04.019. 
Rahman, M., Khosravi, S., Chang, K.H., Lee, S.M., 2016. Effects of dietary inclusion of astanxanthin on growth, muscle pigmentation and antioxidant capacity of juvenile rainbow trout (Oncorhynchus mykiss). Prev. Nutr. Food Sci. 21 (3), 281-288. https://doi.org/10.3746/pnf.2016.21.3.281.

Rueda, F.M., López, J.A., Martínez, F.J., Zamora, S., Divanach, P., Kentouri, M., 1997. Fatty acids in muscle of wild and farmed red porgy, Pagrus pagrus. Aquac. Nutr. 3, 161-165. https://doi.org/10.1046/j.1365-2095.1997.00088.x.

Schuchardt, D., Vergara, J., Fernández-Palacios, H., Kalinowski, C.T., Hernández-Cruz, C.M., Izquierdo Robaina, L., 2007. Effects of different dietary protein and lipid levels on growth, feed utilization and body composition of red porgy (Pagrus pagrus) fingerlings. Aquac. Nutr. 14, 1-9. https://doi.org/10.1111/J.13652095.2007.00484.X.

Smith, G.A., Nichols, P.D., White, D.C., 1986. Fatty acid composition and microbial activity of benthic marine sediment from McMurdo sound, Antarctica. Microbiol. Ecol. 38, 219-231. https://doi.org/10.1111/j.1574-6968.1986.tb01732.x.

Stephanou, D., Georgiou, G., Shourkri, E., 1995. Reproduction and larval rearing of the common seabream (Pagrus pagrus), an experimental culture. Cah. Options Mediterr. 16, 79-87.

Teimouri, M., Amirkolaie, A.K., 2015. The effects of synthetic pigments on pigmentation of Pethia conchonius (Hamilton, 1822). Aquac. Res. 46, 1156-1161. https:// doi.org/10.1111/are.12271.

Tejera, N., Cejas, J.R., Rodríguez, C., Bjerkeng, B., Jerez, S., Bolaños, A., Santamaría, F.J., Lorenzo, A., 2007. Pigmentation, carotenoids, lipid peroxides and lipid composition of skin of red porgy (Pagrus pagrus) fed diets supplemented with different astaxanthin sources. Aquaculture 270, 218-230. https://doi.org/10.1016/j. aquaculture.2007.01.019.

Tejera, N., Cejas, J.R., Rodriguez, C., Jerez, S., Perez, J.A., Felipe, B.C., Lorenzo, A., 2010. Pigmentation, carotenoids, lipid peroxides and lipid composition of red porgy (Pagrus pagrus) skin reared under open-cage conditions. Aquac. Res. 41, 1043-1053. https://doi.org/10.1016/j.aquaculture.2007.01.019.

Tornaritis, M., Peraki, E., Georgulli, M., Kafatos, A., Charalambakis, G., Divanach, P., Kentouri, M., Yiannopoulos, S., Frenaritou, H., Argyrides, R., 1994. Fatty acid composition and total fat content of eight species of Mediterranean fish. Int. J. Food Sci. Nutr. 45, 135-139. https://doi.org/10.3109/09637489409166152.

Torrissen, O.J., Christiansen, R., Struknaes, G., Estermann, R., 1995. Astanxanthin deposition in the flesh of Atlantic salmon Salmo salar in relation to dietary astaxanthin concentration and feeding period. Aquac. Nutr. 1, 77-84. https://doi.org/10.1111/j.1365-2095.1995.tb00022.x.

Trattner, S., Pickova, J., Park, K., Richard, J., Dabrowski, K., 2007. Effects of $\alpha$-lipoic and ascorbic acid on the muscle and brain fatty acids and antioxidant profile of the South American pacu Piaractus mesopotamicus. Aquaculture 273, 158-164. https://doi.org/10.1016/j.aquaculture.2007.09.025.

Van der Salm, A.L., Martínez, M., Flik, G., Wendelaar Bonga, S.E., 2004. Effects of husbandry conditions on the skin colour and stress response of red porgy, Pagrus pagrus. Aquaculture 241, 371-386. https://doi.org/10.1016/j.aquaculture.2004.08.038.

Van der Salm, A.L., Pavlidis, M., Flik, G., Wendelaar Bonga, S.E., 2006. The acute stress response of red porgy, Pagrus pagrus, kept on a red or white background. Gen. Comp. Endocrinol. 145, 247-253. https://doi.org/10.1016/j.ygcen.2005.09.010.

Wang, Y.J., Chien, Y.H., Pan, C.H., 2006. Effects of dietary supplementation of carotenoids on survival, growth, pigmentation, and antioxidant capacity of characins, Hyphessobrycon callistus. Aquaculture 261, 641-648. https://doi.org/10.1016/j.aquaculture.2006.08.040.

Wassef, E.A., Chatzifotis, S., Sakr, E.M., Saleh, N.E., 2010. Effect of two natural carotenoid sources in diets for gilthead seabream, Sparus aurata, on growth and skin coloration. J. Appl. Aquac. 22 (3), 216-229. https://doi.org/10.1080/10454438.2010.497741.

Weil, C., Lefèvre, F., Bugeon, J., 2013. Characteristics and metabolism of different adipose tissues in fish. Rev. Fish Biol. Fish. 23, 157-173. https://doi.org/10.1007/ s11160-012-9288-0.

White, D.A., Ørnsrud, R., Davies, S.J., 2003. Determination of carotenoid and vitamin A concentrations in everted salmonids intestine following exposure to solutions of carotenoid in vitro. Comp. Biochem. Physiol. 136B, 683-692. https://doi.org/10.1016/s1095-6433(03)00222-8.

Woo, M., Jeon, S., Kim, H., Lee, M., Shin, S., Shin, Y., Park, Y., Choi, M., 2010. Fucoxanthin supplementation improves plasma and hepatic lipid metabolism and blood glucose concentration in high-fat fed C57BL/6N mice. Chem-Biol- Interact. 186, 316-322. https://doi.org/10.1016/j.cbi.2010.05.006.

Yi, X.W., Xu, W., Zhou, H.H., Zhang, Y.J., Luo, Y.W., Zhang, W.B., Mai, K.S., 2014. Effects of dietary astaxanthin and xanthophylls on the growth and skin pigmentation of large yellow croaker Larimichthys croceus. Aquaculture 433, 377-383. https://doi.org/10.1016/j.aquaculture.2014.08.035.

Zar, J.H., 2010. Biostatistical Analysis, 5th edition. Prentice-Hall/Pearson, Upper Saddle River, p. 944. xiii. 